\title{
The Relationships among Sport Tourism Attraction, Bikeway Image, Tourism Satisfaction and Revisit Intension of Jiayo Bikeway in Taiwan
}

\author{
Chieh-Chung Hsieh \\ Lecturer \\ National Chiayi University \\ Taiwan
}

\begin{abstract}
Previous tourism studies examined the relationships among image, satisfaction and revisit intension behavior. In recent years, research trends compared to geography and environmental psychology in the field, sport tourism issue is a new subject in tourist areas. Therefore, the study aimed to examine the linkage between these variables and sport tourism. The structural relationships between the variables were examined by adopting a structural equation modeling (SEM) approach. The results showed that Sport tourism image had the most important direct effect on revisit intension. Also, tourism image had an indirect effect on revisit intention as mediated by attraction and satisfaction respectively. In addition, the relationships among sport tourism attraction, image, tourist satisfaction, and revisit intention appeared evidence in this study. In the future, the main focus of government should be to build up and improve tourism image dimensions, such as offering diverse services and products for tourists, creating more exotic sentiments and entertainment, displaying interesting bikeway street performances and stall characteristic.
\end{abstract}

Keyword: image, satisfaction, attraction, revisits intention

\section{Chapter I}

\section{Introduction}

\section{Background}

Bicycle is a traditional transportation vehicle. Nowadays, it is not only a bicycle but also it is an exercise machine. People ride bicycle to decrease transportation cost and to get exercise to get health. Especially people like to ride bicycles together on weekend. Sports Affairs Council of Executive Yuan suggested a project to increase sport population in 2002. it hoped the bicycle sport population could come to 300,000 in 2007 (Sports Affairs Council of Executive Yuan,2002).It was estimated that bicycle sport population will come to 700,000 in 2008 by Council for Economic Planning and Development of Executive Yuan. The SA (Sports Administration, Ministry of Education) has devoted itself to the following policies:

\section{Promoting the "Coming-of-Age Ceremony on a Bike".}

The SA's promotion of the "coming-of-Age Ceremony on a Bike" has been inspired by President Ma Ying-jeou's $600 \mathrm{~km}$ bike adventure accomplished in September 2007. Youngsters are encouraged to learn more about their homeland by taking a bicycle tour. Not only leaving behind a beautiful memory, such a feat can also put their will and perseverance to test. The ceremony is divided into three parts. Those who have turned 16 are invited to complete a $100 \mathrm{~km}$ ride in the community where they have grown up. After 18, the goal is to try riding across counties and cities for a total of $500 \mathrm{~km}$. Signifying their adulthood attainment-turning 20 -will be a $1,000 \mathrm{~km}$ island-wide tour. Boys and girls are thus encouraged to learn the true meaning of "gratefulness, responsibility and sharing" before they are officially initiated into the adult world.

\section{Constructing a Comprehensive Bike Path Network.}

The citizens of Taiwan increasingly look forward to the comprehensive and safe bike path network that many Europeans have long taken for granted. Building on what is already in place, the SA is set to implement a multiyear program for building a national network of cycle lanes. Other than taking into account the specific requirements of each region and offshore islands, the network will connect all the "green corridors" to be found throughout the country. 
The goal is to formulate a larger coastal round-the-island network and a smaller island network also spanning the entire island. By 2012, the SA expects to complete an additional 1,500 km of cycle lanes, which will constitute 17 county-level regional networks.

Since health consciousness gains ground and energy price increases, people ride bicycle activity is the best choice among sports and is the best way to conserve energy and reduces carbon. On the other hand, bikeway is constructed like a raging fire to let people experience the funny of riding bicycle. Taiwan has constructed 40 paths at the end of 2007. they combine natural view and humanities environment utilizing road and public transportation system to plan and construct riding path all over the nation. The total length has come to 1,180 kilometers all over Taiwan (Council for Economic Plan and Development, 2008). Chiayi city government promotes bikeway construction very enthusiastically. They constructed a bikeway along the Jiayo railway to supply a nice environment to exercise in the morning and take a walk in the evening. The total length is 3.5 kilometers. Since it is newly completed recently and the reaction of local people and tourists is very important for government's policy reference. This paper would like to investigate the factors about revisiting intention of Jiayo bikeway in Chiayi city.

Research Problem

Jiayo bikeway is recently constructed in Chiayi city. If the authorities can continue to increase revisit intention to catch more tourists' favors and revisit, this study will be helpful for both local economic and cultural development.

1. Previous studies examined the structural relationships among image, attraction, satisfaction and revisit intention behavior. From the economic perspective, According to Mat Som et al. (2011: 178), "previous studies show $2 \%$ increase in customer retention has the same effects on profits in terms of cost cutting by $10 \%$ ". Study on revisit intention is vital for tourism businesses. Furthermore, preserving loyal tourists is an important contribution to the profitability of business (Hsu et al., 2008).

2. How to preserve tourists' high revisit intention to Jiayo bikeway? Government and local managers are pursuing the answer.

3. Which is better at predicting revisit intention to Jiayo bikeway? the image ,attraction or tourist satisfaction?

4. Does image have a positive effect on revisit intention?

5. Does attraction have a positive effect on revisit intention?

6. Does satisfaction have a positive effect on revisit intention?

To base on the research outcome, we can look forward to bring up great contributions on tourism industryand make the marketing strategies.

Objective of the Study

This research investigates the variables including Tourism Image, Tourism Attraction, Tourist Satisfaction and Revisit Intention in order to talk about the relationship within the case of Jiayo bikeway in Taiwan Chiayi city.

Our objective in this paper attempts to observe and present tourists' behaviors, favors, occupation and age group and present a conceptual framework for enhance customer revisit intention. Next, to analyze the effects of Tourism Image, Tourism Attraction and Tourist Satisfaction on the tourists' Revisit Intention on the Jiayo bikeway. Third, to address some suggestions about how to enhance the tourists willing to revisit Jiayo bikeway in Taiwan .

\section{Expected Results}

The expected result of this research is testing and verifying the factors of tourism image, tourism attraction and tourist satisfaction have the positive effect on the revisit intention. We expect to get the statistical relationships among variables and the information behind relationships. We expect to offer effective suggestions and advices to government through this research.

\section{Scope of Study}

This study focused on the opinions of local people and tourists of Chiayo bikeway. The local people maybe take exercise in the morning and in the evening everyday. Tourists may visit here on Saturday and Sunday. Data was collected about demographic situation and image, attraction, satisfaction after visiting Chiayo bikeway via questionnaire. They are different groups and have different opinions about Chiayobikeway. 


\section{Limitation of the Study}

1. This research focuses on the opinions of local people and tourists of Chiayo bikeway, so the results can be referenced but cannot be inferred to other bikeways.

2. The research methodology is via questionnaire. So we suppose that people answer questions seriously. The measure might have some bios resulted by the recognition and cooperation of the sample.

\section{Definitions of Terms}

Tourist Attraction: A tourist attraction is defined as a system comprising three elements: a tourist or human element, a nucleus or central element, and a marker or informative element. A tourist attraction comes into existence when the three elements are connected (Leiper, 1990: 371)

Bikeway Image: An image is an artifact, for example, a two-dimensional picture, that has a similar appearance to some subject - usually a physical object or a person. We define bikeway image as the perception of specific bikeway of bicycle rider that will influence the riders' image. Sport Tourist Satisfaction: the extent of overall pleasure or contentment felt by the tourist. According to Kozak and Rimmimgton (2000), tourist satisfaction is important to successful destination marketing because it influences the choice of destination, the consumption of products and services, and the decision to return satisfaction is important to successful destination marketing. Tourist satisfaction in this study, we refer the Fornell (1992), defined as the overall feeling when customers buying or after using the products and services. Revisit Intention: Revisit intention is defined as repurchase intention and behavior that demonstrates the willingness to recommend and disseminate positive information for a service provider. Revisit intention is an indicator used to predict customer purchase behavior (Jang \& Namkung, 2009).

\section{Chapter Ii}

\section{Review of Related Literature}

This chapter will focus on the review of literature related to research objective and research problem. It includes Theory of planned behavior, image, tourist satisfaction, revisit intention, theoretical framework, conceptual framework, research hypotheses.

\section{Theory of Planned Behavior}

Over the past few decades, a number of theories have been developed and tested in different contexts for understanding human behavior. Ajzen (2002) claimed that the theory of planned behavior is one of most influential and popular conceptual frameworks to study human behavior. The theory of planned behavior was initially proposed by Ajzen in 1999, and it has received great attention in the literature. For example, the literature reveals that the theory of planned behavior has been cited in 18,475 studies as of Jan. 6, 2012 by searching in Google Scholar. In the same way,the theory of planned behavior has been listed as a key phrase by 1,099 dissertations or theses and 353 articles. The theory of planned behavior has been applied into different topics and supported by most studies which applied the theory such as leisure (Ajzen \& Driver, 1992; Hrubes et al., 2001; Pierro, Mannetti \& Livi, 2003; Latimer et al., 2005; Chatzisarantis \& Biddle, 1998), tourism (Han et al., 2011; Greenslade\& White, 2005; Lam \& Hus, 2006), therapeutic recreation (Galea \& Bray,2006), health behavior (Conner et al., 2002), consumer behavior (Pavlou\&Fygenson,2006; Kassem, et al., 2003), etc.

The theory of planned behavior is an extension of the theory of reasoned action introduced by Fishbein \& Ajzen in 1975. Both theories were rooted in the social psychology field and used to explain informational and motivational influences on behavior (Conner \& Armitage, 1998). Like the theory of reasoned action, the concept of intention to perform a given behavior is central to the theory of planned behavior. In the theory of planned behavior, people's intentions can predict his/ her behavioral performance. Intentions are "assumed to capture the motivational factors that influence a behavior; they are indications of how hard people are willing to try, or how much of an effort they are planning to exert, in order to perform the behavior"(Ajzen, 1991: 181). A behavioral intention can best be elucidated as an intention for planning to perform a certain behavior (Ajzen, 2002). Generally speaking, when people have a stronger intention to engage in a behavior, they are more likely to perform the behavior (Ajzen, 1991). The link between intention and behavior is the reflection that people tend to engage in behaviors they intend to perform. As Doll and Ajzen (1992) indicated, when people have complete control over behavioral performance, intention should be sufficient to predict behavior. 
According to the theory of planned behavior, an individual's intention is determined by three conceptually independent predictors: attitudes, subjective norms, and perceived behavioral control toward a specific behavior (see Figure 1).

In combination, attitude, subjective norms, and perception of behavioral control toward a specific behavior lead to the establishment of a behavioral intention (Ajzen, 2006). The first predictor, attitude, is a person's behavioral beliefs and positive or negative evaluation of the behavior in question (Latimer \& Martin Ginis, 2005). Fishbein and Ajzen (1975) defined attitude as "a learned predisposition to respond in a consistently favorable or unfavorable manner with respect to a given object".

As Rhodes, et al. (2006) mentioned, attitude has a main effect on the predictability of exercise intentions and behavior. However, Fishbein and Ajzen (1975) claimed that attitude alone is hard to predict a behavior; it should aggregate with other variables. The second predictor, subjective norms, is function of normative beliefs, which means the perceived social pressure to perform the behavior or not (Ajzen, 1991). As Ajzen (2002) pointed out, a person's perceptions toward a specific behavior is influenced by pressure groups. Thus, there should be a need to understand how subjective norms play an important role in a person's behavioral decision. The last predictor influencing an individual's intention is perceived behavioral control (PBC), which is the difference between the theory of reasoned action and the theory of planned behavior. Perceived behavioral control means the perceived ease or difficulty of performing the behavior is assumed to reflect past experience as well as anticipated impediments and obstacles (Ajzen, 1991). The theory of planned behavior is expanded from the theory of reasoned action by adding this concept.

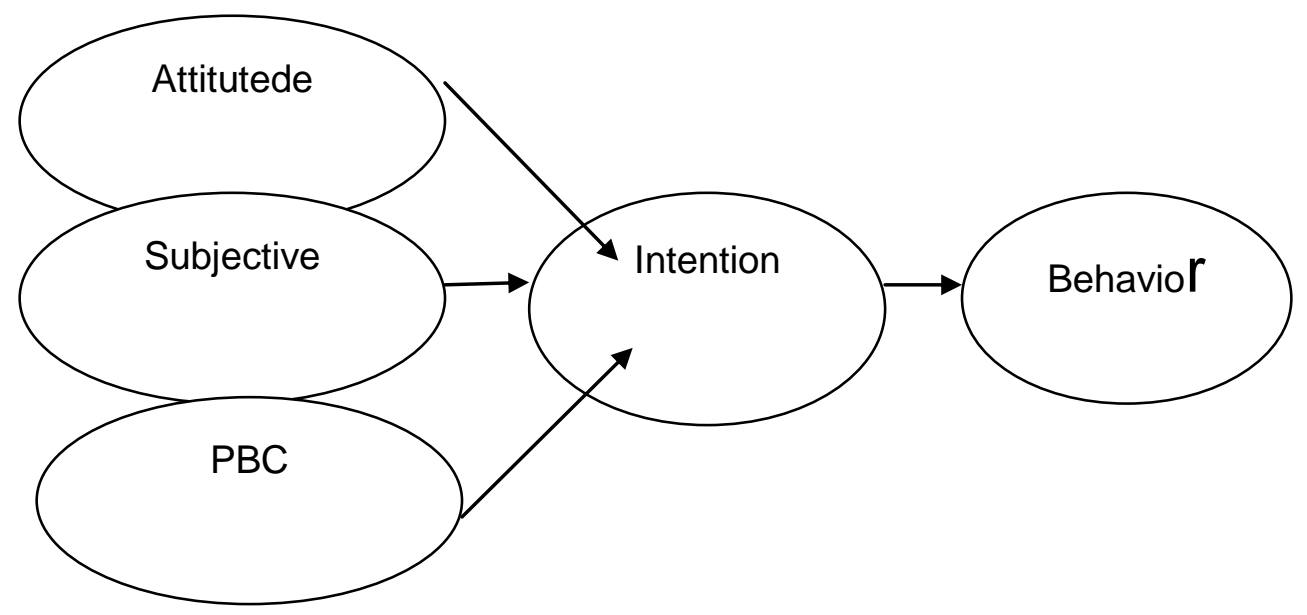

Figure 1The theory of planned behavior

Hausenblas et al. (1997) applied the theory of reasoned action and the theory of planned behavior to exercise behavior and concluded that the theory of planned behavior is more useful than the other one. Thus, we can say that perceived behavioral control really plays an important part in the theory of planned behavior. According to the theory of planned behavior, perceived behavioral control and behavioral intention can be used directly to predict behavioral achievement; however, the relative importance of intention and perceived behavioral control in the prediction of behavior is expected to differ in various situations and behaviors (Ajzen\& Driver, 1992). As a general rule according to the theory of planned behavior, the more favorable the attitude and subjective norm with respect to a behavior, and the greater the perceived behavioral control, the stronger should be an individual's intention to perform the behavior under consideration (Ajzen, 1991).

\section{Image}

Image plays an essential role in geography, marketing, psychology and tourism academic research since Boulding(1956) proposing that human behavior depends upon perceived image rather than an objective reality. The concept of "image" in the tourism research included the terms of "tourism image", "tourism destination image" and "destination image". In general, the terms of "tourism image", "tourism destination image" and "destination image" all have the similar meaning they all adopt the "destination" to be the object of the image. (Crompton, 1979; Moutinho, 1987; Lawson and Baud-Bovy, 1997) 
There is broad agreement among authors regarding the influence of tourism image on the behavior of individuals (Ashworth \& Goodall, 1988; Mansfeld, 1992). Since tourism image is defined by many authors as an individual's overall perception or total set of impressions of a place (Hunt, 1975; Fakeye \& Crompton, 1991; Phelps, 1986) or as the mental portrayal of a destination (Crompton, 1979; Kotler et al, 1993; Middleton, 1994; Milman \& Pizam, 1995; Alhemoud \& Armstrong, 1996; Seaton \& Benett, 1996), which influence over tourists' behavior (Cooper et al., 1993). Recently, Martin and Bosque (2008) joined rational and emotional interpretations from tourists to define tourism image as multi-dimensional. Most comprehensive tourism image definition defined by Echtner and Ritchie (1991) comprises attribute, holistic, functional, psychological, common and unique components. "Destination image" has become a common discussion issue of tourism in the past three decades (Pike, 2002) since it affects the individual's subjective perception, satisfaction, consequent behavior and destination choice (Stabler, 1988; Telisman-Kosuta, 1989; Chon, 1990; 1992; Echtner and Ritchie, 1991; Rittichainuwat et al, 2001; Beerli and Martin, 2004; O'Leary and Deegan, 2005; Loureiro and Gonzalez, 2008) which becomes a critical factor in a tourist's decision process. The image of the tourism destination is a complex construct. Baloglu and McCleary (1999) proposed a framework of tourism image formation, which provide a comprehensive guideline for understanding the complexity of destination image.

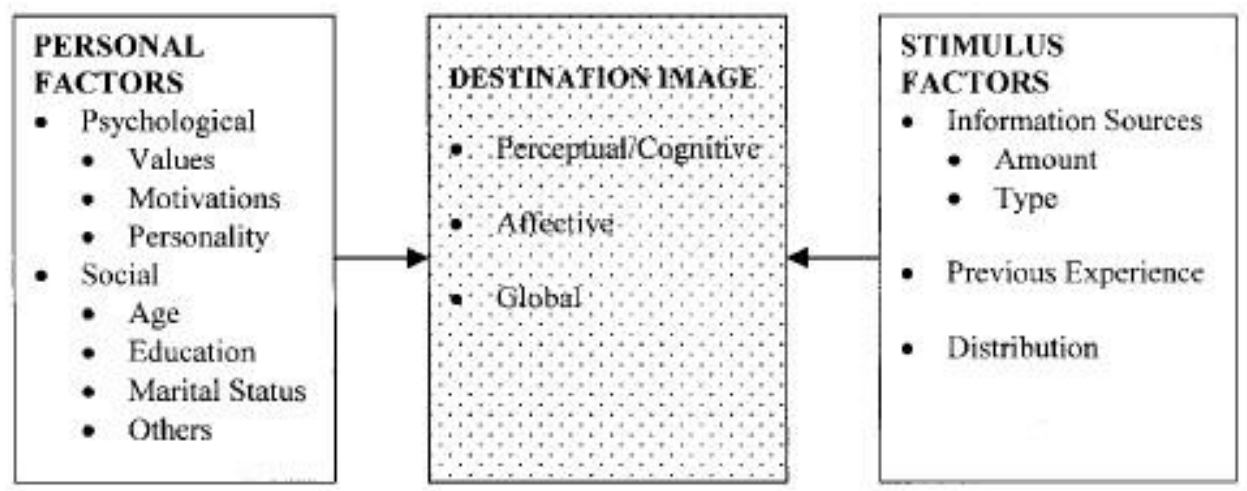

Figure 2 General framework of destination image formation

This framework demonstrates that personal factors, stimulus factors, cognitive and affective factors were all significant in formulating a destination image. In addition to the framework, many studies have provided important findings to support this framework. Gallarza et al. (2002)'s research described the importance of information source. Then, they concluded that perceptions are more crucial than the realities and perceptions are the real motivator for travelling. Moreover, many scholars have defined destination image or tourism image related to the combination of cognitive and affective images (Dobin \& Zinkhan, 1990; Hanyu, 1993; Vaughan \& Edwards, 1999; Martine \& Bosque, 2008). Hanyu (1993) suggested that "affective meaning refers to the appraisal of the affective quality of environments while perceptual/cognitive quality refers to the appraisal of physical features of environments" Studies have identified the value that people give to tourism destinations, not only through knowledge but though an emotional response related to the place (Liljander and Strandvick 1997; White 2002; Yu and Dean 2001). More importantly, behavior might be influenced by the affective quality of an environment rather than by its objective properties directly (Russel and Sonodgrass, 1987 cited in Baloglu and Brinberg, 1997). However, affective image has been overlooked in recent researches. Pike (2002) conducted a review of 142 research papers during 1973 to 2000: only six papers joined the affective image into the evaluation. Tourism image researches have been mostly destination based, which evaluate a particular destination's overall image (Pike, 2002; Lee et al., 2006; Choi et al., 1999). From this thought, it overlooked the significant component's impacts on overall image of a destination.

\section{Tourist Satisfaction}

Esu and Arrey (2009) demonstrated that Past research revealed that customer satisfaction is an important theoretical and practical issue. For most marketers and consumer researchers, customer satisfaction is regarded as a marketing tool to attract the most variable segments of the market. According to Kozak and Rimmimgton (2000) tourist satisfaction is important to successful destination marketing because it influences the choice of destination, the consumption of products and services, and the decision to return satisfaction is important to successful destination marketing; Philip and Hezlett (1996) recognize the fact that one of the strategic routes used by leisure firms in gaining competitive edge has been through an increase concentration in customer satisfaction. 
They also seem to be agreement in the fact that, customer satisfaction influences the choice of destination, the consumption of products and services and the decision to return. Customer satisfaction is increasingly becoming a corporate goal as more and more companies strive for quality in their product or service.

The phenomenology of customer satisfaction has received so much attention by both academics and practitioners in the field of marketing and psychology. The common theories underpinning the concept of customer satisfaction are:

1. The expectation-disconfirmation model (Oliver, 1980a).

2. Expectation-perception gap model (Parasuraman et al., 1985).

3. Performance-only model (Pizman and Millman, 1993).

4. Pivotal-core-peripheral (PCP) model (Philip and Hazlett, 1996).

Akama and Kieti (2002) found that Tourists, like other customers, usually have initial expectations of the type and quality of services to be offered in a particular destination. These expectations are formed mainly through information provided via tourism advertisements, commercials, brochures, mass media and informal information from friends and relatives. The extent to which tourist expectations are met will eventually determine the level of tourist satisfaction. If the overall performance, while or after visiting a destination, exceeds or meets initial expectation then the tourist is considered satisfied. However, if perceived performance falls below initial expectation then the tourist may be dissatisfied. Customer satisfaction is increasingly becoming a salient issue in most service industries. With reference to the tourism and hospitality industry, it can be stated that satisfied tourists are more likely to recommend the tourist destination to others, which is the cheapest and most effective form of marketing and promotion (Crosby, 1993; S.oderlund, 1998). Furthermore, tourist satisfaction usually contributes to increased rates of the retention of tourists' patronage, loyalty and acquisition, which in turn helps in realizing economic goals like increased number of tourists and revenues. As a consequence, there is usually a positive association between tourist satisfaction and the destination's long term economic success. Moreover, tourists can express their satisfaction through many ways such as positive word of mouth, paying compliments to the service or product provider and development of long-term loyalty to the destination. At the same time, through tourist satisfaction, the relationship between the tourist and the tourist destination is strengthened.

Bitner and Hubbert (1994) describe customer satisfaction as a feeling or an attitude of a customer towards a service after it has been used. Studies have also confirmed that there is a relationship between service quality, satisfaction and behavioral intention and then service quality and behavioral intention. As defined by Cronin and Mackey (1992: 127) service quality reflects a consumer's evaluative perceptions of a service encounter at a specific point in time. In contrast, customer satisfaction judgments are experimental in nature, involving both an end-state and process, and reflecting both emotional and cognitive elements. In the field of marketing, and leisure, there is a general acceptance of the claim that service quality influence overall customer satisfaction (Lee et al., 2004; Valle et al. 2006; Huh, 2002; Crompton and Love, 1995; Parasuraman et al., 1988; Cronin and Mackey, 1992). Huh (2002) wrote that Several researchers have studied customer satisfaction and provided theories about tourism (Bramwell, 1998; Bowen, 2001). For example, Parasiraman et al.'s (1985) expectation perception gap model, Oliver's expectancy- disconfirmation theory (Pizam and Milman, 1993), Sirgy's congruity model (Sirgy, 1984; Chon and Olsen, 1991), and the performance - only model.(Pizam et al., 1978) have been used to used to measure tourist satisfaction with specific tourism destinations. In particular, expectancy- disconfirmation has received the widest acceptance among these theories because it is broadly applicable.

Pizam and Milman (1993) utilized Oliver (1980b) expectancy-disconfirmation model to improve the predictive power of travelers' satisfaction. They introduced the basic dynamic nature of the disconfirmation model into hospitality research, while testing part of the original model in a modified form. In order to assess the causal relationship 13 between two different disconfirmation methods, they employed a regression model with a single "expectation - met" measure as the dependent variable, and 21 difference-score measures as the independent variables. Some studies on customer satisfaction are also notable in tourism behavior research. For example, Pizam et al. (1978) investigated the factor structure of tourists' satisfaction with their destination areas. The authors showed eight distinguishable dimensions of tourist satisfaction. Barsky and Labagh (1992) introduced the expectancy-disconfirmation paradigm into lodging research. Basically, the proposed model in these studies was that customer satisfaction was the function of disconfirmation, measured by nine "expectations met" factors that were weighted by attribute - specific importance. The model was tested with data collected from 100 random subjects via guest comment cards. 
As a result, customer satisfaction was found to be correlated with a customer's willingness to return. Chon and Olsen (1991) discovered a goodness of fit correlation between tourists' expectations about their destination, and tourists' satisfaction. Then, after tourists have bought the travel service and products, if the evaluation of their experience of the travel product is better than their expectations, they will be satisfied with their travel experience. Furthermore, Chon and Olsen (1991) provided an intensive literature review of tourist satisfaction. One thing to be noted, however, is that although the posited social cognition theory offers an alternative way of explaining satisfaction processes, its methodological mechanism is analogous to that of expectancy-disconfirmation theory.

In other words, the concepts of congruity and incongruity can be interpreted similarly to the concepts of confirmation and disconfirmation, both of which can result in either positive or negative directions. Pizam et al. (1978) stated that it is important to measure consumer satisfaction with each attribute of the destination, because consumer dis/satisfaction with one of the attributes leads to dis/satisfaction with the overall destination. Furthermore, Rust, Zahorik, and Keininghan (1993) explained that the relative importance of each attribute to the overall impression should be investigated because dis/satisfaction can be the result of evaluating various positive and negative experiences.

\section{About the dimension there are two ways to measure it:}

Overall attitude dimensions measured: Anderson, Fornell and Lehmann (1994) considered that the overall customer satisfaction means a consumer product or service for a full purchase and consumption experience, and formed by the accumulation over time, the overall evaluation. Oliver (1997) that measure the overall attitude of the way for consumers to self-important attribute to their weighting, to more accurately reflect the true level of satisfaction of consumers. Cole and Scott (2004) studied that the overall satisfactions for the tourists in an area the overall feel of the collection of satisfaction. Multi-attribute dimensions measure: Zeithaml and Bitner (2000) believes that satisfaction is extensive, it was Brand image, perceived value, the relationship between customer satisfaction and customer loyalty - A Case Study of Travel Overseas Group Package Tour 67 service quality, product quality, price, situational factors and personal factors. Lee et al. (2004) that the measurement of tourist satisfaction with the overall sense of pleasure, desire and willingness to pay level of dissatisfaction. Millán and Esteban (2004) study of customer satisfaction in the travel industry, the use of confirmatory factor analysis approach, summarize the measurement of multiple dimensions of customer satisfaction for the service encounter, empathy, the reliability, service environment, comments efficiency, additional attributes and other six dimensions measure. Yoon and Uysal (2005) in travel motivation, satisfaction and loyalty study destination that tourist satisfaction measurement to the desired level of satisfaction, the value of tourism experiences in the past compared tourist areas. In summary, Tourists express satisfaction or dissatisfaction after they buy tourism products and services (Fornell, 1992). If tourists are satisfied with the products, then they will have the motivation to buy them again or they will recommend them to their friends. Tourist satisfaction in this study, we refer the Fornell (1992), defined as the overall feeling when customers buying or after using the products and services.

\section{Revisit Intention}

Thomas (1995) study also pointed out that the cost of attracting new customers is five times the cost of maintaining existing customers. According to Reichheld and Sasser (1990) study, when companies increased by $5 \%$ on customer retention rates, the profit will increase $25 \%$ to $85 \%$.Thus; loyal customers will be the main source of competitive advantage, so keep loyal customers of the business are concerned and a very important task. Drake, Gwynne, and Waite (1998) pointed out that loyalty can be divided into behavioral, cognitive, and affect factors. Behavioral loyalty means customer actuary buying behavior, cognitive behavioral loyalty intentions concerning the future customers' behavior. Emotional loyal means the attitude of the enterprise from customers. And customers who have a good impression on the enterprise most likely turn to long-term loyalty. So the attitude is an important factor in Loyalty. Smith (1998) pointed out that when customers strongly feel that a company has the best ability to meet their needs, and this status cannot be replaced by other firms, then the customers have a "loyalty" to the enterprise. Bowen and Shoemaker (1998) also argued that customer loyalty is a repeat purchase behavior, and seems themselves as their business partners. In summary, customer loyalty can be divided into behavioral and psychological aspects of performance, and this performance could reduce customer turnover rate, and create a competitive advantage. Sirgy, Morris and Coskun (1985) noted that customer loyalty as a customer has a tendency to repeat shopping for a particular store. Customer loyalty is also defined as a kind of relationship between personal attitudes and repurchases behavior (Dick \&Basu, 1994). 
Jones and Sasser (1995) defined customer loyalty as a customer has a sense of belonging or identity to the company's staff, services or products, such feelings will directly affect the follow-up customer's buying behavior. The study also further divided loyalty into long-term loyalty and short-term loyalty: long-term customer loyalty means consumer buy a particular brand of product or service, not easy to change the selection; short-term loyalty means when customers have a better selection of products or store, the customer will immediately change their decision. Cavero and Javier (1997) pointed out that customer loyalty is the customer has a preference for a particular company's products and will not consider the products of other companies when they need to repurchase.

Oliver (1997) also believe that customer loyalty is the customers have a consistent and strong intention in future re-purchase product, therefore repetitive purchase the same brand, not because of changes in circumstances and marketing activities transfer their behavior and impact. Smith (1998) proposed customer loyalty means when the customers really get products and services from the seller, and these products and services did not expect from the seller's competitors.

In addition, Fredericks, Hurd, and Slater (2001) reported that the concept of customer loyalty offer the proposed of "share of customer" loyalty to this quantitative measure; relative to the pursuit of market share in traditional businesses, the so-called customer share is trying to sell more goods to the same customer, in other words, for a specific type of consumer, trying to get customers on goods or services in a specific proportion reached the highest ratio of value, if the customer spend higher budget can be classified as the more loyal customers. Reichheld and Schefter (2000) thought that "customer loyalty" is to the right customers for the trust, in other words, to find worth customers to investment, and obtain the commitment to this customer relationship. According to the literature review, this study is defined "customer loyalty" as "the customer identity and preferences of the company's services or products, and in the future have a strong willingness to re-purchase or repetitive purchase the same brand and its combination, not because of the situation changes or marketing activities to transfer behavior, also the customer will be voluntary to create a positive word of mouth for the company." Reichheld et al. (1990) demonstrated that satisfaction of the customer will increase loyalty for business, and increase loyalty of customers means that the probability of repeat purchase in the future will be substantially increased. Since the past few years the rise of the Internet, also caused rapid amplification of the number of global sites. How each site survive and highlight out in the online world, it must rely on customer loyalty, that is, company web site master by loyalty. (Smith, 2001)

Reichheld et al.(1990) first proposed, "the network loyalty" (E-Loyalty) the term refers to the customer loyalty resulting from transactions over the Internet. Smith (2001) also mentioned in the study, some sites boast that they have millions of registrations, and that such growth to show they have a network loyalty. But the real measure of loyalty is customer to attend the network again and the level of interaction. For the measurement of customer loyalty in dimensions, in general, there is the attitude side, behavioral and comprehensive three ways to measure it. To measure customer attitudes often refers to emotional and psychological level. But customers may often occur a behavior: they like a company or brand or product but not consumption. This phenomenon is found by the products may be too expensive. (Toh et al., 1993), if use the only way to measure the level of customer loyalty through the attitude will cause bias. The behavioral measure often as repurchase intentions as index characteristics, but customer purchase behavior cannot be representative of the brand loyalty (TePeci, 1999). So to overcome this deficiency can be measured by a combination and integrated improvement, and then more accurately predict ratio on customer loyalty (Pritchard and Howard, 1997). Later, most scholars tend to measure customer loyalty integrated way. (Wong and Sohal, 2003; Baumann et al., 2005).Methlie and Nysveen (1999) in a study on customer loyalty in online banking divided customer loyalty into emotional loyalty (Affective Loyalty) and attitudinal loyalty (Conative Loyalty). Customer loyalty refers to the emotional perception that the bank is better than the other competitors, and it is more like the bank; attitude of customer loyalty is to continue use the bank's intentions in the future. Parasuraman et al. (1985) on "The Behavioral Consequences of Service Quality" in the article, customer loyalty should include: the positive reviews of companies, the firm recommended to potential customers, friends and business transactions advocates, business-first priority during purchase options, and increase future transactions with the enterprise. In addition, as many scholars divided loyalty into attitude loyalty and behavior loyalty attitude, therefore, the two have different measurement methods. Chaudhuri and Holbrook (2001) in "The chain of effects from brand trust and brand affect to brand performance: the role of brand loyalty" a text, use the "next time when I buy a similar product, I will choose this brand again", and "I will continue to buy this brand of products" as two indicators to measure consumer behavior loyalty. 
Meanwhile, the author uses "I have some commitment to the brand", and "I am willing to pay a higher price than other brands to buy this brand of goods" and other two indicators, to measure consumer attitudes loyalty.

Roberts et al. (2003) noted that use of information sharing, positive reviews refer a friend, continued to buy, purchase additional services and try the new service six indicators to measure customer loyalty. In the competitive environment, manufacturers have been able to achieve customer satisfaction, but still unable to retain customers, the main reason is that company's lack of customer loyalty. Customer loyalty, after all, is the source of long-term profitability. Reichheld et al. (1990) that the real value of customer loyalty is cash benefits. Shoemarker and Lewis (1999) find that "loyalty triangle" model (Royalty triange) to build customer loyalty framework.

(A) Service process: the process of service operation including all customers and service providers to join in all activities. (B) Value Creation: Including value added and access. (C) Database Management / Communication: Building the customer preference database to provide customers with special services, and use advertising mail notification and contact customer about their contact and activity. It can be seen, in addition to new customers, the sources of the customers from the results of other companies which change "action loyalty" and the company's customer retention, therefore, it is the key changes affecting customer loyalty to the company's financial profitability. Kandampully (1998) also approached that customer loyalty is a web business's commitments and guarantees to quality service this study suggests that customer loyalty is caused by the inner psychological customer loyalty, with repeat purchase behavior characteristics and help the company to propagate are customer loyalty behaviors. Although the measure of customer loyalty for the scholars do not the same, but in the form of "repurchase intention" and "willingness to recommend" two indicators seems as higher rates of repetition. Although the indicators "repeat purchase" rate is not low, but according to scholars demonstrated that measure the customer loyalty by customer dealing with a company and repurchase intention at any time who ask the customer whether the re-purchase of specific products or services' intention in the future. The explanation could understand the behavior of repeat purchase intention is to the performance of the repurchase behavior (Heskett et al., 1994).

This study is based on Hui et al. (2007) research. Used 2 items to measure the tourist's revisit intention, the first of all is "likelihood of revisiting", and the second one is "likelihood of recommendation". Hui et al. (2007) that the environmental impact and marketing practices could potentially lead customer loyalty to the conversion behavior, customer "to re purchase" this preferences for the product or service unchanged. For a description of the network customer loyalty, customer loyalty will be defined as "a deeply held commitment to rebuy or repatronize a preferred product/service consistently in the future, thereby causing repetitive same-brand or same brand set purchasing, despite situational influences and marketing efforts having the potential to cause switching behavior". And "fervently desires to re-buy a product or service and will have no other - pursuing this quest against all odds and at all costs" (Oliver, 1997: 36)

\section{Theoretical Framework}

Theoretical Framework Explanation: the framework describes the relations among bikeway image, tourist satisfaction, sport tourism attraction and revisit intention. This Theoretical Framework is constructed as follows. First, Kozak (2001) suggested that repeat visitors are more likely than first time visitors to return to the same destination in the future and the level of overall satisfaction considerably influences intentions for repeat visits. Therefore, tourist satisfaction with the destination would influence revisit intentions, which in turn, lead to revisit behavior. Bigné et al. (2001) empirically investigated structural interrelationships among destination image, quality, satisfaction, and after-purchase behavior. Their findings confirmed that destination image not only directly affects quality, satisfaction, and future behavior but also indirectly affects future behavior through quality and satisfaction. Tourists are likely to develop emotional attachment with destinations they visit, and this psychological attachment could be an important antecedent and a sensible measure of tourist loyalty to a destination (George \& George, 2004; Lee, Backman, \& Backman, 1997). 


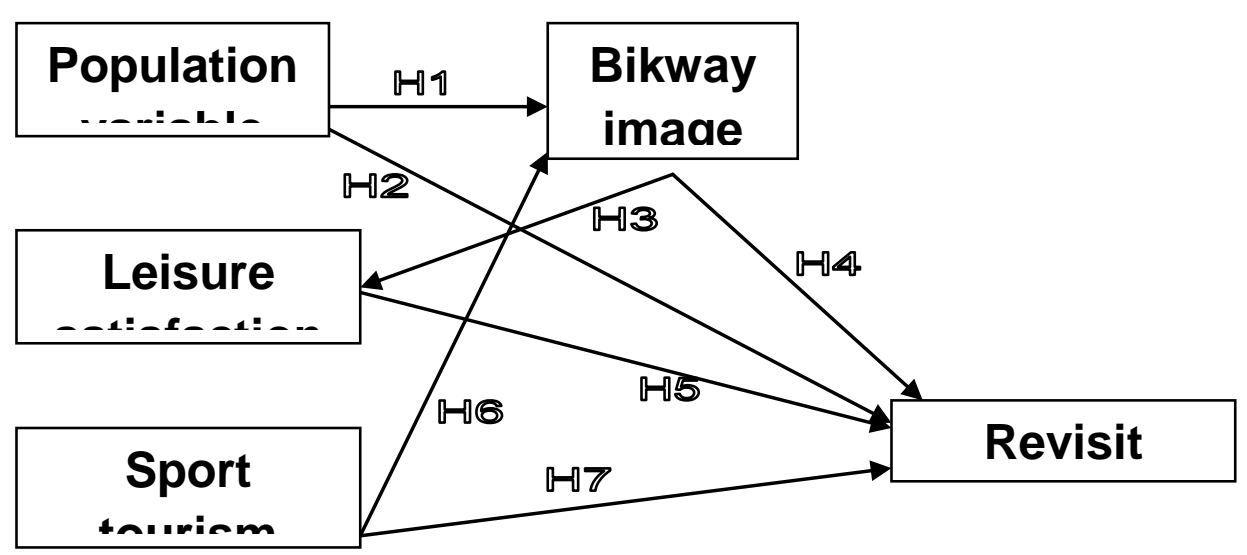

\section{Conceptual Framework}

Figure 3Theoretical Framework

Conceptual Framework is constructed as follows. First, conceptual background and hypotheses one to seven are proposed based on an evaluation of previous research. Next, the Methodology will be outlined. Subsequently, a model, including tourism image, sport tourist satisfaction, sport tourism attraction and revisit intentions, is specified, based by the appropriate dimensions by scholar's definition followed by the results. Also, for the originality value of the paper is completed by a conclusion and implications through analysis the questionnaires. In this study, the new proposed causal relationships among these variables will be developed from theory and examined empirically.

1. Sport tourism image Scales: The measurement of tourism image, we summed up of several researches, they divided the tourism image into two kinds of image (Cognitive image and Affective image) Separated them into 3 dimensions included "environment", "facilities"and "bikeway planning".

2. Tourists Satisfaction Scales: Tourists satisfaction measured on the item refers to Cole and Scott (2004). The concept of the tourism products and services for the overall measure of satisfaction for tourist there are 6items:"psychology", "education", "social relationship","relaxation","physiology" and "aesthetic".

3. Sport tourism attraction: Sport tourism attraction conceptualization consisted of measures capturing 3 dimensions: "sport dimension","space dimension" and "time dimension".

4. Revisit Intention Scales: Revisiting Intention was measured using an adapted version of the Hui et al. (2007) scale. Used 2 items to measure the tourist's revisit intention, the first of all is "likelihood of revisiting", and the second one is "likelihood of recommendation".

\section{Figure 4Conceptual Framework}

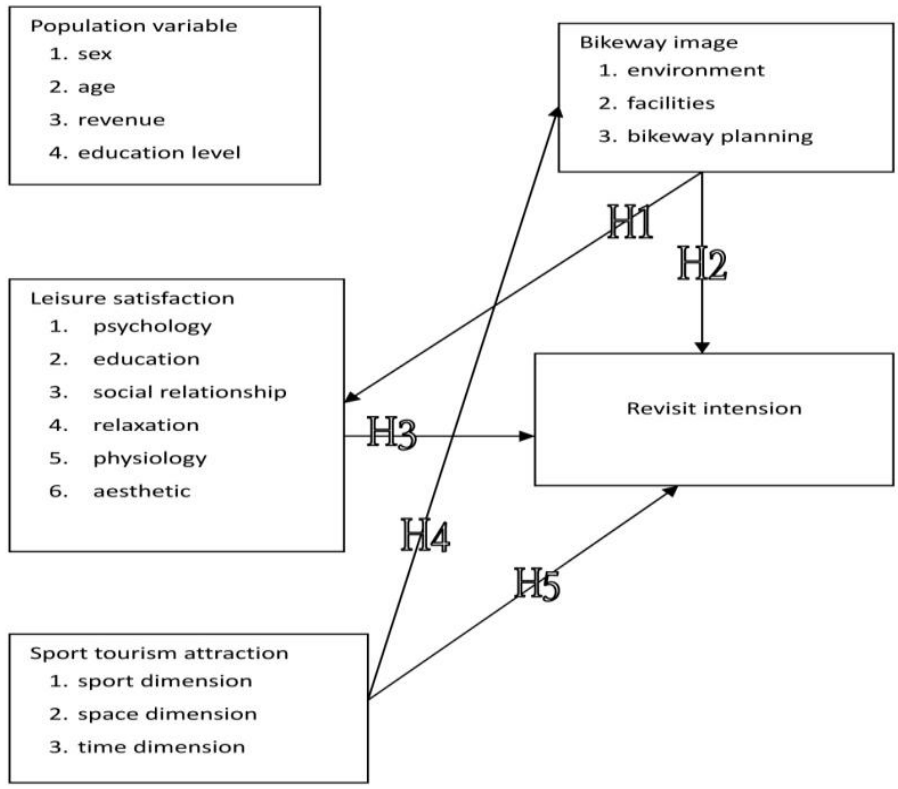




\section{Research Hypotheses}

According to the research framework, this research brings up 5 hypotheses. The inference process and the hypotheses elaborated in the follow contents.

\section{Consequences of Tourism Image:}

Kotler, Bowen, and Makens (1996) consider that the following sequence could be established: image $\rightarrow$ attraction $\rightarrow$ satisfaction $\rightarrow$ revisit intention. In this way, tourism image would affect how customers perceive attraction . Tourism image exercises a positive influence on attraction and satisfaction, because it moulds the expectations that the individual forms before the visit, and these variables depend on the comparison of such expectations with experience (Font, 1997; Phelps, 1986) as suggested by Grönroos (1984).

In tourism, Appiah-Adu et al. (2000); Heung and Cheng (2000) and Kozak and Rimmington (2000) suggest that attraction is an antecedent of satisfaction. In tourism, Court and Lupton (1997) found as a result of their study of the image of New Mexico, that the image of the tourism destination positively affected an intention to revisit in the future. Andreassen and Lindestd (1998a) mentioned that in the service industries, the company image is an important factor to affect the attraction, the consumers' satisfaction and the loyalty. Fombrun and Shanley (1990) also addressed the advantages of the positive image; the positive image will bring the additional profit and inhibit the competitors in the same industry. Moreover, the positive image will help to get the higher profit and make the customer to consider that the company has good products and good service and easy to attract more talent for the company.

Bigné et al. (2001) considered that the tourism destination image will affect tourists' behavior. Actually, for the destination there were not good or bad, the value of the destination will depend on the different of the emotion links to the tourism market (Davidoff \& Davidoff, 1983). Furthermore, the attractions from the previous experience and tourism image will have inference on the tourists' revisit intention for a tourism destination (Lee, 2001). And the researchers Hou et al. (2005) also addressed that the attractions of different tourism destination images will affect the intensity of the revisit intention between different groups. Combinations of the above, we concluded that the tourism image will affect the tourists' behavior, and then that will have some inference on the revisit intention. Thus, the following four first hypotheses are:

H1: bikeway image has a positive influence on leisure satisfaction.

$\mathrm{H} 2$ : bikeway image has a positive influence on revisit intentions.

H3: leisure satisfaction has a positive influence on revisit intentions.

H4: sport tourism attraction has a positive influence on bikeway image.

H5: sport tourism attraction has a positive influence on revisit intentions.

\section{Chapter Iii}

\section{Research Methodology}

\section{Locale of the Study}

The locale of this study focused on Jiayo bikeway. Jiayo bikeway is built by using local idle old railway. Bike road lies on both sides of original railway. In accordance with local terrain and the landscape features, government sets open space station, landscape layout, and Lotus pool. It starts from Chinese Petroleum Corporation (CPC) Chiayi factory, along with Chiayi City District and the Chiayi County shuishangxiang and Terminal is tropic station of astronomical square, full length about 3,500 meters. It is Chiayi City District emerging dedicated bike road and the landscape step road. The entire lane runs through Chiayi City, linking urban and rural pastoral scenery, scenery full of blue skies, green space.

Population and Sampling Procedures

Population

The population of this study focused on the tourists who visited the Jiayo bikeway and local people.

\section{Sampling}

In all forms of research, it would be ideal to test the entire population, but in most cases, the population is just too large that it is impossible to include every individual. This is the reason why we rely on sampling techniques like convenience sampling, the most common of all sampling techniques. WE prefer this sampling technique because it is fast, inexpensive, easy and the subjects are readily available. Follow the convenient sampling approach. 
A survey was conducted face-to-face collect primary information to help understand the tourists' local people's opinion. The randomly selected tourists and local people were asked questions from a questionnarie. Statistical accuracy is a function of sample size. The larger the sample size, the more the statistical accuracy of the results. At some point though, the increase in statistical accuracy may not be worth the additional cost. A sample size of 400- often referred to as the "'Magic 40"- which gives a statistical accuracy of + or - 5\% is thought of as the most cost effective sample size. We collected 600respondents' questionnary answer sheets and the valid sample size is 572.

\section{Measurement of Variable}

In this study would take the questionnaire survey. The questionnaire adopts Likert-type scale with 5 degrees, and uses the criteria of the measurement as follows: 5= Strongly Agree, $4=$ Agree, $3=$ Neutral, $2=$ Disagree and 1= Strongly Disagree, to measure the respondents' intention for each question. Moreover, after the data analysis, we can discuss the degree of the agreement, if gets the point between of $4.21-5.00$, that means strongly agrees with the argument; if gets the point between of $3.41-4.20$, that means agrees with the argument; if gets the point between of $2.61-3.40$, that means neutral with the argument; if gets the point between of $1.81-2.60$, that means disagrees with the argument; finally, if gets the point between $1.00-1.80$, that means strongly disagrees with the argument. The measurement of variable of each concept and the items in every concept will be discussed in the follows.

\section{Tourism Image}

The measurement of tourism image, we summed up of several researches included Fakeye and Crompton (1991); Echtnerand Ritchie (1993); Baloglu and McCleary (1999); Chen and Kerstetter (1999); Chaudhary (2000); Baloglu and Mangaloglu (2001) they divided the destination image into two kinds of image (Cognitive image and affective image) then separated them into 10 dimensions included "Space", "Amenities", "Historic and cultural spot", "Price level", "Atmosphere", "People", "Local cuisine", "Traditional handicraft/Souvenir", "Security" and "Affective feeling".

\section{Table 1 Tourists' image Scale}

\begin{tabular}{lll}
\hline \hline No. & Variable & $\begin{array}{l}\text { Variable } \\
\text { name }\end{array}$ \\
\hline 1. & Jiayo bikeway has Multiple natural view & IMA1 \\
2. & Jiayo bikeway has Many kinds of flowers and trees & IMA2 \\
3. & Jiayo bikeway has good air quality & IMA3 \\
4. & Jiayo bikeway has wide view & IMA4 \\
5. & Jiayo bikeway has no car disturbance & IMA5 \\
6. & Jiayo bikeway has suitable distance to drive & IMA6 \\
7. & Jiayo bikeway has good leisure equipment at tropic of Cancer & IMA7 \\
\hline \hline
\end{tabular}

Source: Fakeye and Crompton (1991); Echtner and Ritchie (1993); Baloglu and McCleary (1999); Chen and Kerstetter (1999); Chaudhary (2000); Baloglu and Mangaloglu (2001)

\section{Attraction}

The measurement of attraction adapted from Garvin's research (1987).

Table 2Tourists' attraction Scale

\begin{tabular}{lll}
\hline \hline No. & Variable & Variable name \\
\hline 1. & I can increase Physical Fitness & ATT1 \\
2. & I can earn leisure happiness & ATT2 \\
3. & I can improve driving skill & ATT3 \\
4. & Jiayo bikeway has beautiful field scenery & ATT4 \\
5. & Jiayo expresses different experience in four seasons & ATT5 \\
\hline \hline
\end{tabular}

Source: Garvin (1987) 


\section{Tourists' Satisfaction}

Tourists' satisfaction measured on the item refers to Cole and Scott (2004), the concept of the tourism products and services for the overall measure of satisfaction for tourist .

Table 3Tourists' Satisfaction Scale

\begin{tabular}{lll}
\hline No. & Variable & Variable name \\
\hline 1. & I become healthier & SAT1 \\
2. & I increase self-confidence & SAT2 \\
3. & It is a new type of exercise & SAT3 \\
4. & I can accumulate leisure experience & SAT4 \\
5. & Ican make acquaintance of newfriends & SAT5 \\
6. & I relax body and spirit & SAT6 \\
7. & I resolve nervous living & SAT7 \\
8. & I increase muscular endurance & SAT8 \\
9. & I can lose weight & SAT9 \\
\hline \hline
\end{tabular}

Source: Cole and Scott (2004)

\section{Revisit Intention}

Revisiting Intention was measured using an adapted version of the Hui et al. (2007) scale (see Table 4). They used 2 items to measure the tourist's revisit intention, the first of all is "likelihood of revisiting", the second one is "likelihood of recommendation".

Table 4 Revisiting Intention Scale

\begin{tabular}{lll}
\hline \hline No. & Variable & $\begin{array}{l}\text { Variable } \\
\text { name }\end{array}$ \\
\hline 1. & I am willing to revisit theJiayo bikeway. & REV1 \\
2. & I am willing to recommend Jiayo bikeway. & REV2 \\
\hline \hline
\end{tabular}

Source: Hui, Wan and Ho(2007)

\section{Research Instrument}

The variables included of Tourism Image, Attraction, Tourist Satisfaction, and Revisit Intention. In this research, the variable is defined and measured way stated the following: First, tourism image: the reference to Fakeye et al., (1991); Echtner et al., (1993); Baloglu et al., (1999); Chen et al., (1999); Chaudhary (2000); Baloglu et al., (2001) had description of the tourism image of the site, the tourism image is defined as including Cognitive image and Affective image.

Second, satisfaction: According to Kozak and Rimmimgton (2000) tourist satisfaction is important to successful destination marketing because it influences the choice of destination, the consumption of products and services, and the decision to return satisfaction is important to successful destination marketing. The description of the satisfaction is defined asoverall pleasure felting by the tourist, resulting from the bikeway's experience. This study refers to Cole and Scott (2004) the concept of the tourism products and services for the overall measure of satisfaction for tourist.

The last, revisiting Intention: used 2 items to measure the tourist's revisit intention, the first of all is "likelihood of revisiting", the second one is "likelihood of recommendation" It was measured using an adapted version of the Hui et al. (2007) scale.

\section{Pretesting of the Instrument}

To test the effectiveness of the survey questionnaire, it is necessary to pretest it before actually using it. In this research adopts the undeclared pretest, and does not tell respondents that it is a pretest. The survey is given just like to conduct it for real. This type of pretest allows checking the choice of analysis and the standardization of the survey. (Converse and Presser, 1986)

According to Narins (1999) pointed that it is difficult to say how many participants to have per pretest. A rule of thumb is a sample of 25 to 75 for a large-scale study. And on the book "Making Health Communication Programs Work: A Planners Guide" had the chapter to discuss about the planning and pretest, it mentions that in pretest the sample size should be large enough, however, to give the confidence that have sampled a range of opinions. 
A reasonable and adequate sample size is 50 participants typical of the target audience. According to the references in this study will get 50 participants in the pretest process. This study used the confirmatory factor analysis to test the reliability and validity. In confirmatory factor analysis, Cronbach's alpha is used to measure the reliability of two or more construct indicators. Furthermore, in confirmatory factor analysis, to check the measurement model validity, the number of the indicator helps us. For example, in confirmatory factor analysis, the factor loading latent variable should be greater than 0.7. Chi-square test and other goodness of fit statistics like RMR, GFI, NFI, RMSEA, SIC, BIC, etc., are some key indicators that help in measuring the model validity in confirmatory factor analysis. (Statistics Solutions, 2009: online).

\section{Data Gathering}

Data gathering is a term used to describe the process of preparing and collecting data. The purpose of data gathering is to obtain information, to keep on record to make decisions about important issues, to pass information on to others (Weller \& Romney 1988). Primarily, data is collected to provide information regarding a specific topic.

Since accurate data about the population is not available, the sample in this study will be collected via an on-site survey. In order to survey a maximum number of visitors over a relatively small period of time, a selfadministrated questionnaire will be distributed to participants who are selected at the exit of the main gate of the study areas. A limitation of this type of survey may involve self-selection biases because it involves a nonprobability sampling method. However, it is at the researchers' discretion to determine who will be the most useful and representative, so it is deemed a useful method for researchers to do the sampling (Babbie, 2010). In addition, with the intention of collecting a representative sample, the on-site survey will be conducted on weekends. Before doing the questionnaire, the researchers explained and outlined the purpose of the study to the participants. After getting approval, the self-administrated questionnaire was given to each participant. All subjects were selected based on their willingness to volunteer their personal information on site.

The data gathering plan in this study will contain the following activities:

Pre-collection activity: get the target data for pretesting use, and make sure the analysis methods. Collection: follow the sampling approach to collect data. Present findings: involve some form of sorting analysis and paper work. Following the sampling approach and data gathering plan, this study will adopt the questionnaire survey. We visited local people who took exercise or took a walk at the bikeway and marked their address in order to avoid double visiting. Also, we asked tourists who rode on the bikeway at the spot. Since they finished riding ,they could express their image, satisfaction, attraction and revisit intention of the bikeway. Tourists would be marked their address in order to avoid double visiting, too. The data collection period span for 2 months. We took the morning and evening to collect data of local people when they left home to take a walk or exercise. And collect data of tourists who rode bicycle on the jiayo bikeway on weekend.

\section{Analysis of Data}

About the analysis of the data, in this research used 2 kinds of statistic software, Statistical Package for Social Science (SPSS) and Structure Equation Model (SEM). For descriptive data analysis, T-test, and regression analysis, SPSS was used. SEM was used to do confirmation factor analysis and test the model and the multidirectional relationship.

\section{Descriptive Analysis}

Descriptive analysis is used to describe the main features of a collection of data quantitatively. The analysis aims to provide an overview of the respondents and an insight into their behavioral patterns. (Mann, 1995)

\section{Confirmatory Factor Analysis}

In statistics, confirmatory factor analysis (CFA) is a special form of factor analysis. It is used to test whether measures of a construct are consistent with a researcher's understanding of the nature of that construct (or factor). In contrast to exploratory factor analysis, where all loadings are free to vary, CFA allows for the explicit constraint of certain loadings to be zero. CFA has built upon and replaced older methods of analyzing construct validity. CFA is commonly used in social research. CFA is frequently used when developing a test, such as a personality test, intelligence test, or survey (Asparouhov \& Muthén, 2009).

For some applications the requirement of zero loadings for indicators not supposed to load on a certain factor has been regarded as too strict. 
A newly developed analysis method, Exploratory Structural Equation Modeling, specifies hypothesis about the relation between observed indicators and their supposed primary latent factors while allowing for estimation of loadings with other latent factors as well (Asparouhov \& Muthén, 2009).

SEM (Structural Equation Modeling)

Structural equation modeling (SEM) is a statistical technique for testing and estimating causal relations using a combination of statistical data and qualitative causal assumptions. This definition of SEM was articulated by the geneticist Wright (1921) and the cognitive scientist Simon (1953) and formally defined by Pearl (2000) using a calculus of counterfactuals. Among the strengths of SEM is the ability to construct latent variables: variables which are not measured directly, but are estimated in the model from several measured variables each of which is predicted to 'tap into' the latent variables. This allows the modeler to explicitly capture the unreliability of measurement in the model, which in theory allows the structural relations between latent variables to be accurately estimated. Factor analysis, path analysis and regression all represent special cases of SEM. (Bollen \& Long, 1993).

\section{CHAPTER IV}

Investigate the Tourists' Present Situation

Respondents' Demographic Backgrounds

Firstly, Descriptive analysis will be used to describe the main features of a collection of data quantitatively. The analysis aims to provide an overview of the respondents and an insight into their behavioral patterns (Mann and Lacke, 1995). The descriptive analysis of demonstrative variables is as table 5. gender range is between 1-2. 51.6\% people is male and $48.4 \%$ is female. Local people is almost $49.7 \%$ and $50.3 \%$ is nonresident people. $15.2 \%$ is student, $14.2 \%$ is public servants, $12.2 \%$ is industry and commerce, $15.7 \%$ self-employment, $16.1 \%$ service, $14.7 \%$ agriculture, and $11.9 \%$ housekeeping. We may conclude that the sample is composed of more male people, half of the sample is local people, most people are self-employment, house-keeping people are very few. The descriptive analysis of response data is as table 6 .

Table 5 Descriptive Analysis of Demonstrative Variables

\begin{tabular}{lllll}
\hline Item & Frequency & Percentage & $\begin{array}{l}\text { Effective } \\
\text { percentage }\end{array}$ & $\begin{array}{l}\text { Cumulative } \\
\text { percentage }\end{array}$ \\
\hline GENDER & & & & \\
Male & 295 & 51.6 & 51.6 & 51.6 \\
Female & 277 & 48.4 & 48.4 & 100.0 \\
RESIDENT & & & & \\
Local & 284 & 49.7 & 49.7 & 49.7 \\
Non-resident & 288 & 50.3 & 50.3 & 100.0 \\
OCCUPATION & & & & \\
agriculture & 84 & 14.7 & 14.7 & 88.1 \\
industry and commerce & 70 & 12.2 & 12.2 & 41.6 \\
public servants & 81 & 14.2 & 14.2 & 29.4 \\
self-employment & 90 & 15.7 & 15.7 & 57.3 \\
service industry & 92 & 16.1 & 16.1 & 100.0 \\
housekeeping & 68 & 11.9 & 11.9 & 15.2 \\
student & 87 & 15.2 & 15.2 & \\
Total & 572 & 100.0 & 100.0 & \\
\hline \hline
\end{tabular}


Table 6The descriptive analysis of response data

\begin{tabular}{lll}
\hline & \multicolumn{2}{l}{ Respondent(n=572) } \\
\cline { 2 - 3 } Variable NAME & Mean & $\begin{array}{l}\text { Standard } \\
\text { Deviation }\end{array}$ \\
\hline I can increase Physical Fitness & 3.45 & 1.414 \\
I can earn leisure happiness & 3.49 & 1.427 \\
I can improve driving skill & 3.57 & 1.415 \\
Jiayo bikeway has beautiful field scenery & 3.60 & 1.437 \\
Jiayo expresses different experience in four seasons & 3.66 & 1.420 \\
Jiayo bikeway has Multiple natural view & 3.52 & 1.402 \\
Jiayo bikeway has Many kinds of flowers and trees & 3.53 & 1.467 \\
Jiayo bikeway has good air quality & 3.49 & 1.444 \\
Jiayo bikeway has wide view & 3.47 & 1.421 \\
Jiayo bikeway has no car disturbance & 3.54 & 1.435 \\
Jiayo bikeway has suitable distance to drive & 3.43 & 1.501 \\
Jiayo bikeway has good leisure equipment at tropic & 3.23 & 1.431 \\
of Cancer Park & 3.44 & 1.489 \\
I am willing to revisit theJiayo bikeway. & 3.51 & 1.398 \\
I am willing to recommend Jiayo bikeway. & 3.48 & 1.397 \\
I become healthier & 3.31 & 1.399 \\
I increase self-confidence & 3.45 & 1.435 \\
It is a new type of exercise & 3.52 & 1.488 \\
I can accumulate leisure experience & 3.48 & 1.445 \\
I can make acquaintance of new friends & 3.51 & 1.478 \\
I relax body and spirit & 3.44 & 1.438 \\
I resolve nervous living & 3.50 & 1.409 \\
I increase muscular endurance & 3.26 & 1.429 \\
I can lose weight & & \\
\hline \hline
\end{tabular}

We may discuss the implication of table 6 as follows:

1. The mean ranges from 3.23 to 3.66. It means the respondents answerthe questions neutrally and are inclined to agree.

2.The standard deviation ranges from 1.397 to 1.501. It means respondents answer the questions don't spread widely. Their answers concentrate on 2,3 and 4.

3. We may roughly summarize that the most attract tourists is "the different experience in four seasons".

4. We may roughly summarize that the best image kept in the tourists' brain is "no car disturbance".

5. We may roughly summarize that the most satisfy tourists is "cummulate leisure experience".

6. We may roughly summarize that the tourists agree to revisit jiayo bikeway and agree to recommend their friends to visit Jiayo bikeway.

\section{Chapter V}

Findings And Analysis The Effects Of Variables

The size of the sample has a direct impact on the appropriateness and the statistical power of the Structural Equation Model (Hair et al., 1998). SEM is not appropriate for sample sizes below 100. As a rule of thumb sample sizes of greater than 200 are suggested (Boomsma 1982; Marsh, Balla\& McDonald, 1988). Following the rules, the sample size in this study was acceptable. The validity of the constructs was tested using the procedure recommended by Fornell and Larcker (1981). Then, confirmatory factor analysis (CFA) was conducted using AMOS 5.0 with covariance matrix to test the convergent and discriminate validity of the constructs used in subsequent analysis. Discriminate validity was tested by comparing the square root of the average variance extracted by each construct to the correlations between the construct and all other constructs. Table 7 shows correlations between the constructs. 
For each comparison, most of the square roots of the average variance extracted estimates from each construct exceeded the correlation between each construct (see table 7). This shows that each construct is statistically different from one another.

Table 7 Analysis of discriminate validity (SEM correlation)

\begin{tabular}{lllll}
\hline \hline Variables & $\begin{array}{l}\text { Tourism } \\
\text { Image }\end{array}$ & Attraction & $\begin{array}{l}\text { Tourist } \\
\text { Satisfaction }\end{array}$ & $\begin{array}{l}\text { Revisit } \\
\text { Intention }\end{array}$ \\
\hline Tourism Image & 0.6780 & 0.6442 & 0.7223 & 0.7221 \\
Attraction & 0.6442 & 0.7554 & 0.822 & 0.5555 \\
Tourist Satisfaction & 0.7223 & 0.8222 & 0.7114 & 0.6661 \\
Revisit Intention & 0.7221 & 0.5555 & 0.6661 & 0.9445 \\
\hline \hline
\end{tabular}

Remark: a: All correlations are significant at $\mathrm{p}<0.05$.

b:Diagonal elements in bold are square roots of average variable extracted (AVE)

Structural Model Analysis

The proposed conceptual model was tested by using the four constructs: namely tourism image, attraction, tourist satisfaction, and revisit intentions. Employing the covariance matrix among measurement items as input, the SEM analysis was conducted to examine the relationships between each pair of constructs as hypothesized. The results of SEM analysis were depicted in Fig.5. The fit indices of the model are summarized in table 8. Indicators of goodness of fit are GFI=0.972, AGFI=0.965, PGFI=0.770, NFI=0.212, RFI=0.096, CFI=0.997, and RMR=0.073. Comparing these with the corresponding critical values shown in table 8, it suggests that the hypothesized model fits the empirical data well. It provides the summary of goodness of fit indices for both the measurement and the structural equation model.

Table 8 Summary of goodness of fit indices for measurement and structural models

\begin{tabular}{llll}
\hline \hline Fit indices & Criteria & Measurement Model Indicators & Structural model Indicators \\
\hline GFI & $>0.9$ & 0.972 & 0.965 \\
AGFI & $>0.9$ & 0.965 & 0.961 \\
PGFI & $>0.5$ & 0.77 & 0.877 \\
NFI & $>0.9$ & 0.212 & 0.0 \\
RFI & $>0.9$ & .096 & 0.0 \\
CFI & $>0.9$ & .997 & 0.0 \\
RMR & $<0.05$ & .073 & .085 \\
\hline \hline
\end{tabular}

Hypothesis test

When we analyze by SEM (structural equation model), we may get the following regression weights as table 9.Critical region(C.R.) is the set of values of the test statistic for which the null hypothesis is rejected. The C.R. value is ranging from 3.44 to 21.121 , which is far beyond $95 \%$ confidence interval $-1.96 \sim+1.96$. We may Conclude that the regression coefficients are not equal to zero and we may reject null hypothesis, which means that the independent variable is significantly affect dependent variables. Independent variable-Tourism Satisfaction significantly affects those dependent variables- attraction, image and revisit variables. Independent variable-Image affects dependent variable-revisit and attraction variable significantly. Satisfaction of accumulating leisure experience affects mostly. Attraction of beautiful field scenery affects significantly, too. Image of variety of natural view and full of trees, flowers and grass affects equally.

Table 9 Regression weights of SEM analysis

\begin{tabular}{llllll}
\hline \hline & & & Estimate & S.E & C.R. \\
\hline ATTRACTION & $<---$ & SATISFACTION & $.931^{*}$ & .144 & 6.475 \\
IMAGE & $<--$ & SATISFACTION & $.461^{*}$ & .089 & 5.154 \\
REVISIT & $<---$ & SATISFACTION & $.507^{*}$ & .148 & 3.440 \\
REVISIT & $<---$ & IMAGE & $.559^{*}$ & .160 & 3.500 \\
REVISIT & $<---$ & ATTRACTION & $.402^{*}$ & .080 & 5.034 \\
I can increase & $<---$ & ATTRACTION & 1.000 & &
\end{tabular}




\begin{tabular}{|c|c|c|c|c|c|}
\hline & & & Estimate & S.E & C.R. \\
\hline $\begin{array}{l}\text { I can earn leisure } \\
\text { happiness }\end{array}$ & $<--$ & ATTRACTION & $.975 *$ & .047 & 20.906 \\
\hline $\begin{array}{l}\text { I can improve driving } \\
\text { skill }\end{array}$ & $<--$ & ATTRACTION & $.982 *$ & .047 & 21.121 \\
\hline $\begin{array}{l}\text { Jiayo bikeway has } \\
\text { beautiful field } \\
\text { scenery }\end{array}$ & $<--$ & ATTRACTION & $.9 * 9 *$ & .047 & 20.901 \\
\hline $\begin{array}{l}\text { Jiayo expresses } \\
\text { different experience } \\
\text { in four seasons }\end{array}$ & $<--$ & ATTRACTION & $.731 *$ & .059 & 12.286 \\
\hline $\begin{array}{l}\text { Jiayo bikeway has } \\
\text { Multiple natural view }\end{array}$ & $<--$ & IMAGE & $2.12 *$ & .250 & 8.497 \\
\hline $\begin{array}{l}\text { Jiayo bikeway has } \\
\text { Many kinds of } \\
\text { flowers and trees }\end{array}$ & $<--$ & IMAGE & $2.12 *$ & .250 & 8.514 \\
\hline $\begin{array}{l}\text { Jiayo bikeway has } \\
\text { good air quality }\end{array}$ & $<--$ & IMAGE & $2.081 *$ & .245 & 8.494 \\
\hline $\begin{array}{l}\text { Jiayo bikeway has } \\
\text { wide view }\end{array}$ & $<--$ & IMAGE & $2.06 * 7$ & .244 & 8.465 \\
\hline $\begin{array}{l}\text { Jiayo bikeway has no } \\
\text { car disturbance }\end{array}$ & $<--$ & IMAGE & $1.031^{*}$ & .170 & 6.081 \\
\hline $\begin{array}{l}\text { Jiayo bikeway has } \\
\text { suitable distance to } \\
\text { drive }\end{array}$ & $<--$ & IMAGE & $.864 *$ & .149 & 5.793 \\
\hline $\begin{array}{l}\text { Jiayo bikeway has } \\
\text { good leisure } \\
\text { equipment at tropic of } \\
\text { Cancer Park }\end{array}$ & $<--$ & IMAGE & 1.000 & & \\
\hline $\begin{array}{l}\text { I am willing to revisit } \\
\text { theJiayo bikeway. }\end{array}$ & $<--$ & REVISIT & 1.000 & & \\
\hline $\begin{array}{l}\text { I am willing to } \\
\text { recommend Jiayo } \\
\text { bikeway. }\end{array}$ & $<--$ & REVISIT & $.964 *$ & .058 & 16.534 \\
\hline I become healthier & $<--$ & SATISFACTION & 1.000 & & \\
\hline $\begin{array}{l}\text { I increase self- } \\
\text { confidence }\end{array}$ & $<--$ & SATISFACTION & $.930 *$ & .160 & 5.805 \\
\hline $\begin{array}{l}\text { It is a new type of } \\
\text { exercise }\end{array}$ & $<--$ & SATISFACTION & $1.033^{*}$ & .168 & 6.157 \\
\hline $\begin{array}{l}\text { I can accumulate } \\
\text { leisure experience }\end{array}$ & $<--$ & SATISFACTION & $2.14 *$ & .264 & 8.146 \\
\hline $\begin{array}{l}\text { I can make } \\
\text { acquaintance of new } \\
\text { friends }\end{array}$ & $<--$ & SATISFACTION & 2.082 & .256 & 8.133 \\
\hline I relax body and spirit & $<--$ & SATISFACTION & 2.091 & .257 & 8.121 \\
\hline $\begin{array}{l}\text { I resolve nervous } \\
\text { living }\end{array}$ & $<--$ & SATISFACTION & $2.044 *$ & .253 & 8.064 \\
\hline $\begin{array}{l}\text { I increase muscular } \\
\text { endurance }\end{array}$ & $<--$ & SATISFACTION & $.969 *$ & .168 & 5.769 \\
\hline I can lose weight & $<--$ & SATISFACTION & $.914 *$ & .164 & 5.588 \\
\hline
\end{tabular}


When we standardized the regression weights, regression weights are ranging from 0.222 to 0.891 . The regression weights larger than 0.8 are the following regression independent variables: Increase physical fitness, earn leisure happiness, improve driving skill, beautiful field scenery, multiple natural view, many kinds of flowers and trees, good air quality, wide view, accumulate leisure experience, make acquaintance of new friends,relax body and spirit, and resolve nervous living. They are important factors that affect tourists' attraction, image and satisfaction level, which will then encourage tourists to revisit again. Showed as table 10

Table 10Estimates of standardized regression weights

\begin{tabular}{llll}
\hline \hline & & & Estimate \\
\hline ATTRACTION & $<---$ & SATISFACTION & .492 \\
IMAGE & $<--$ & SATISFACTION & .468 \\
REVISIT & $<---$ & SATISFACTION & .222 \\
REVISIT & $<--$ & IMAGE & .241 \\
REVISIT & $<---$ & ATTRACTION & .333 \\
Increase Physical Fitness & $<---$ & ATTRACTION & .862 \\
Earn leisure happiness & $<---$ & ATTRACTION & .842 \\
Improve driving skill & $<---$ & ATTRACTION & .849 \\
Beautiful field scenery & $<---$ & ATTRACTION & .846 \\
Different experience in four seasons & $<---$ & ATTRACTION & .584 \\
Multiple natural view & $<---$ & IMAGE & .873 \\
Many kinds of flowers and trees & $<---$ & IMAGE & .877 \\
Good air quality & $<---$ & IMAGE & .888 \\
Wide view & $<---$ & IMAGE & .867 \\
No car disturbance & $<---$ & IMAGE & .404 \\
Suitable distance to drive & $<---$ & IMAGE & .363 \\
Good leisure equipment at tropic of Cancer & $<---$ & IMAGE & .424 \\
Park & & & \\
I am willing to revisit & $<---$ & REVISIT & .872 \\
I am willing to recommend my friend & $<---$ & REVISIT & .891 \\
Become healthier & $<---$ & SATISFACTION & .413 \\
Increase self-confidence & $<---$ & SATISFACTION & .371 \\
New type of exercise & $<---$ & SATISFACTION & .407 \\
Accumulate leisure experience & $<---$ & SATISFACTION & .885 \\
Make acquaintance of new friends & $<---$ & SATISFACTION & .876 \\
Relax body and spirit & $<---$ & SATISFACTION & .872 \\
Resolve nervous living & $<---$ & SATISFACTION & .851 \\
Increase muscular endurance & $<---$ & SATISFACTION & .381 \\
To lose weight & $<---$ & SATISFACTION & .363 \\
\hline \hline
\end{tabular}

According to the statistics which will measure the fitness of model, we get the significant statistics. Showed as table 8. Within the overall model, the estimates of the structural coefficients provide the basis for testing the proposed hypotheses. As shown in Fig. 5, tourism image has a significantly positive effect on revisit intention ( $\square=0.41$, $\mathrm{t}$-value $=2.35, \mathrm{p}<0.01$ ), thus supporting hypothesis.

Tourism satisfaction has a significantly positive effect on tourism attraction $(\square=0.65$, t-value $=3.56, p<0.01$ ), thus supporting hypothesis.

Tourism satisfaction has a significantly positive effect on tourism image ( $\square=0.09$, t-value $=2.47, \mathrm{p}<0.01$ ), thus supporting hypothesis.

Tourism satisfaction has a significantly positive effect on revisit intention ( $\square=0.67$, t-value $=3.264, \mathrm{p}<0.01$ ), thus supporting hypothesis.

Tourism attraction has a significantly positive effect on revisit intention ( $\square=0.31$, $t$-value $=2.984, p<0.01$ ), thus supporting hypothesis. Standardized regression coefficient between latent variables is the direct effect of latent variables or Standardized path coefficient. Standardized regression coefficient of latent variable to indicator variable is standardized factor loading. The square of standardized factor loading $\left(\mathrm{R}^{2}\right)$ is the explained variation from latent variable to indicator variable. 
If $\mathrm{R}^{2}>0.5$ (factor loading $>0.71$ ) then individual indicator variable of latent variable has good reliability. We can compare power of relative affection by standardized coefficient estimates. The attraction construct affect revisit intention most, then Image construct, satisfaction construct is the least one. Their estimates are 0.333, 0.241, 0.222 individually. Indicator variable (Increase Physical Fitness) affects attraction construct most. Its estimate is 0.862.Indicator variable (good air quality) affects image construct most. Its estimate is 0.888 . Indicator variable (Accumulate leisure experience) affects image construct most. Its estimate is 0.885 .shown as table 10.

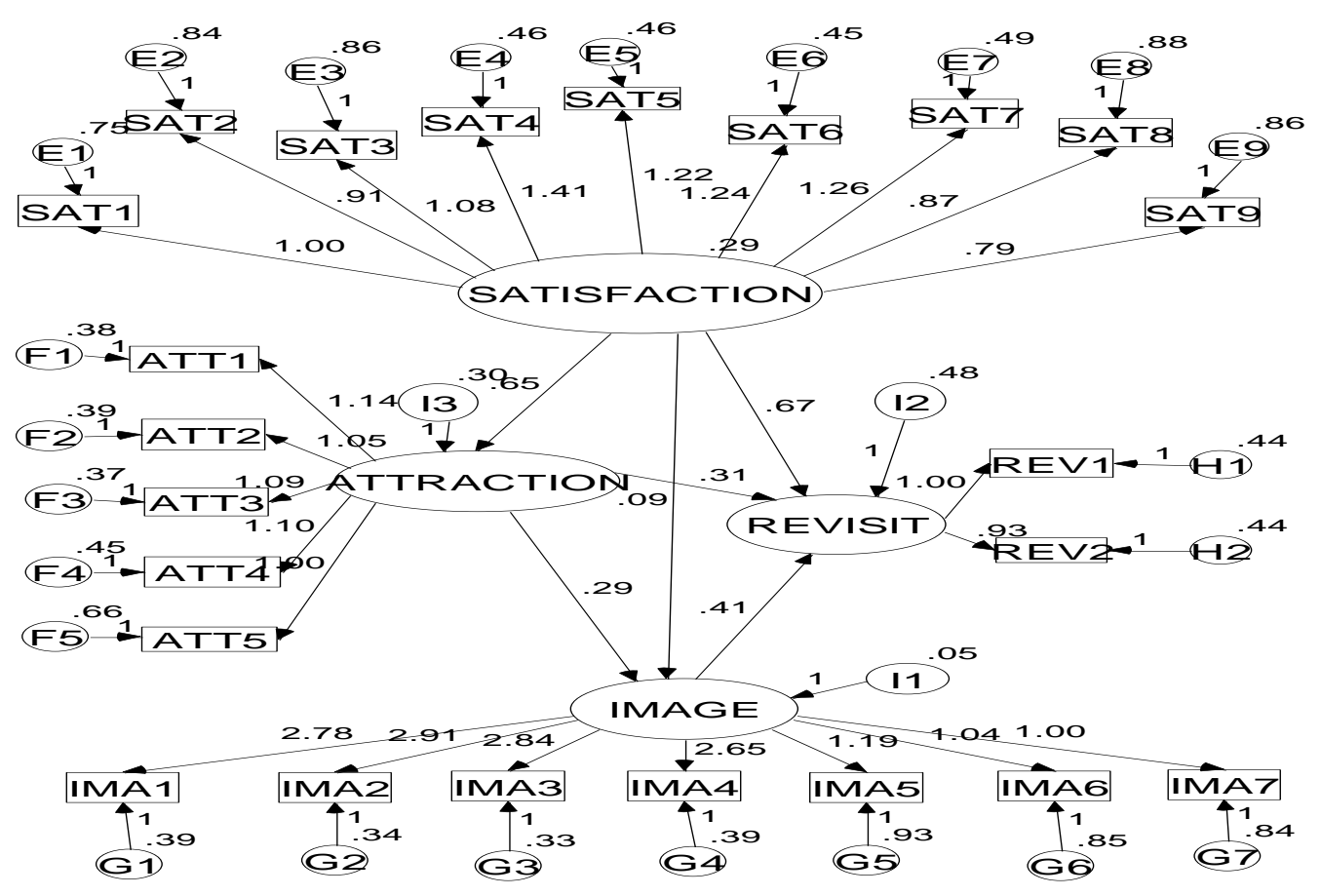

Figure 5The estimated structural model.

Chaptervi

Summary Implication and Recommendation

Summary

The results of the hypotheses testing are summarized as follow :

1. Tourism satisfaction not only influence revisit intentions but also on tourism attraction and tourism image.

2. Tourism image influences on tourists' revisit intention.

3. Good tourism attraction influences on tourists' revisit intention.

According to the SEM analysis result, we find standardized estimates of regression coefficients of indicator variables to latent variables larger than 0.8 are as follow:

Indicator variables affect latent variable attraction are (1) Increase Physical Fitness, (2)earn leisure happiness, (3)improve driving skill and (4)beautiful field scenery .

Indicator variables affect latent variable image are (1)multiple natural view, (2)Many kinds of flowers and trees, (3) good air quality and (4)wide view.

Indicator variables affect latent variable satisfaction are (1)Accumulate leisure experience, (2)make acquaintance of new friends, (3)relax body and spirit and (4)resolve nervous living. The structural relationship analysis indicates that tourism satisfaction has the most important effect on revisit intentions. Moreover, tourism image is also an antecedent of revisit intentions. The result is consistent with Bigné et al. (2001).

In addition, tourism image was also found to have an effect on revisit intentions. Therefore, in order to improve the visitors' revisit intention, the tourism managers should increase the visitors' positive destination image, provide more positive attraction for the bikeway and create higher tourist satisfaction. we think that further research can be carried out to extend the study to different types of tourism destinations and deepen the multidimensional nature of the variables. 


\section{Implication}

According to Mat Som et al. (2011: 178) "previous studies show 2\% increase in customer retention has the same effects on profits in terms of cost cutting by $10 \%$ ". Study on repeat visitation is vital for tourism businesses. Furthermore, preserving loyal customers is an important contributor to the profitability of business (Hsu et al., 2008) Keeping previous customers is better cost-effective than obtaining new ones (Shoemaker \& Lewis, 1999). In tourism industry, the promotional costs of attracting repeat visitors are less than first time visitors (Weaver \& Lawton, 2002; Lau \& Mckercher, 2004). Hence, endeavors to build or improve the image of a destination facilitate loyal visitors revisiting or recommending behaviors, thus being critical to the success of destination tourism development. In other words, the main focus of destination managers should be to build up and improve tourism destination image creating more exotic sentiments and entertainment, displaying interesting bikeway performances and stall characteristic, and making festive atmosphere. As a consequence of the above, tourism destinations managers must take special care of the image that they attempt to communicate and visitors' satisfaction, as these will affect visitors' revisit intentions.

How should government do according to the research result? There are some implications suggested as follow:

1. Creating more beautiful field scenery: there is already beautiful field scenery that attracts tourists very much. Government can pay more attention to maintain it and create some more scenery. for example: building lotus pool with fish ,frog swimming in it. Cut trees stem that is stretching out to cover tourists' eyesight.

2. Maintain good air quality: Jiayo bikeway is full of trees and flowers. The air is fresh and clean. But some local people might take advantage of his own convenience to drive motorcycle on it which emits lots of exhaust. So we might seriously enforce the law to prevent those motorcycles driving on the bikeway.

3. make acquaintance of new friends: Government create activities at the bikeway for tourists and local people. For example: small scale concert like jazz every weekend, birthday celebration, agricultural product exhibition, etc....

\section{Recommendations}

To sum up, this study provides an interesting starting point for empirical research on the relationships among tourism image, attraction, satisfaction and revisit intentions in the Jiayo bikeway. Certainly, refinements in conceptualization and measurement are possible and desirable. Revisit intention has been highlighted as an important research topic in competitive market of tourism destinations. The government may accept our research results and research implication to create more revisit intention. They can also hold photography competition of Jiayo bikeway and post those beautiful pictures on the website to make it famous not only in Taiwan but also over the world.

\section{WE recommend following concrete suggestion:}

1. To announce that every Monday of the week is the concert night. Local people may enjoy music played by local music lovers at 19:00 to 21:00.

2. To announce that every Sunday of the first week of each month is the PARENT-CHILD DAY. The government will send the policemen to maintain the traffic safety of Jiayo bikeway. Parents and children will have happy and safe Parent-child activity on the first Sunday of each month.

\section{Recommendations for Further Study}

In the future, the main focus of government should be to build up and improve tourism image dimensions, such as offering diverse products, creating more entertainment, displaying interesting bikeway performances and stall characteristic, and making festive atmosphere. Time arrangement and cost are hard to make balance. To sum up, as a consequence of the research, government must take special care of the image that they attempt to communicate and visitors' perceived attraction and satisfaction, as these will affect visitors' revisit intention.

In the future, government may pay more attention to study of arranging various activity of each month, so the tourists and local people will revisit Jiayo bikeway again and again. 


\section{References}

Ajzen, I. 1991. "The theory of planned behavior". Organizational Behavior and HumanDecision Processes 50: $179-211$.

. 2002. "Perceived behavioral control, self-efficacy, locus of control, and thetheory of planned behavior". Journal of Applied Social Psychology 32: 665-683.

. 2006. Constructing a TPB questionnaire: conceptual and methodologicalconsiderations. [Online].Available http://www-unix.oit.umass.edu/ aizen/ (July 2010).

Ajzen, I. \& B.L. Driver. 1992. "Application of the theory of planned behavior to leisurechoice". Journal of Leisure Research 24(23): 207-224.

Akama, J. S. and D. M. Kieti. 2002. "Measuring tourist satisfaction with Kenya's wildlife safari: a case study of Tsavo West National Park". Journal of Tourism Management 24: 73-81.

Alhemoud, A. M. and E. G. Armstrong. 1996. "Image of tourism attractions in Kuwait". Journal of Travel Research 34(4): 7.

Anderson, E. W. 1998. "Customer satisfaction and word-of-mouth". Journal of Service Research 1(1): 5-17.

Anderson, E.W., Fornell, C. \& D.R. Lehmann. 1994. "Customer satisfaction, market share, and profitability: Findings from Sweden”. Journal of Marketing 58(3): 53-66.

Anderson, Eugene W. \& M. W. Sullivan. 1993. "The antecedents and consequences of consumer satisfaction for firms". Marketing Science 12(2): 125-143.

Anderson, J. C. \& J. A. Narus. 1990. "A model of distributor firm and manufacturer firm working partnerships". Journal of Marketing 54(1): 42-58.

Anderson, James C. and W. Gerbing,David.1988. "Structural Equation Modeling in Practice: A Review and Recommended Two-Step Approach".Psychological Bulletin 103 (May): 347-362.

Anderson, E. W. and M. W. Sullivan.1990. Customer Satisfaction and Retention AcrossFirms. Cited inZeithaml, Berry, \&Parasuraman (Eds.).1996. Paper Presented at TIMS College of Marketing Special Interest Conference on Service Marketing. Nashville, T. N.: TIMS College.

Andreassen, T. W. and B.Lindestad. 1998. "The effect of corporate image in the formation of customer loyalty".Journal of Service Research 1(1): 82-92.

. 1998. "Customer Loyalty and Complex Service: the Impact of Corporate Image on Quality, Customer Satisfaction and Loyalty for Customers with Varying Degrees of Service Expertise".International Journal of Service Industry Management 9(1): 7-23.

Appiah-Adu, K., A. FyallandS. Singh. 2000. "Marketing culture and customers retention in the tourism industry". The Service IndustriesJournal20(2): 95-113.

Ashworth, G. andB. Goodall. 1988. Marketing in the Tourism Industry the Promotion of Destination Regions. London: Routledge.

Asparouhov, T. andB. Muthén. 2009. "Exploratory structural equation modeling”. Structural Equation Modeling 16: 397-438.

Baloglu, S. andM. Mangaloglu. 2001. "Tourism destination images of Turkey, Egypt, Greece, and Italy as perceived by Us-based tour operators and travel agents". Tourism Management 22: 1-9.

Baloglu, S. andK. W. McCleary. 1999. "A model of destination image formation". Annals of Tourism Research26(4): 868-897.

Balouglu, S. andD. Brinberg. 1997.“Affective images of tourism destinations”.Journal of Travel Research 35: 1115.

BarskyandLabagh. 1992. "A Strategy for Custmer Satisfaction". Cornell Hotel and Restaurant Administration Quarterly33: 32-40.

Bauman, G., L. Bustillos, E. Bensimon, M. C. Brown andR. Bartee. 2005. Achieving Equitable Educational Outcomes with all Students: The Institution's Role and Responsibilities. Washington, DC: Association of American Colleges and Universities.

Beerli, A. andJ.D. Martin. 2004. "Tourists' characteristics and the perceived image of tourist destinations: A quantitative analysis-A case study of Lanzarote, Spain". Tourism Management25: 623-636.

Bigné, J. E., M. I. Sánchez and J. Sánchez. 2001. "Tourism image, evaluation variables and after purchase behaviour: inter-relationship". Tourism Management 22(6): 607-616. 
Bitner, M. J. andA. K. Hubbert. 1994. Encounters satisfaction versus overall satisfaction versus quality. Cited in A. Rao.2005.Multi- attributes of confidence, convenience, price function of customers of financial services firms: a GLS system models. Journal of Financial Services Marketing2(10):1-5.

Bollen, K. A. and S. J. Long. 1993. “Testing Structural Equation Models”. SAGE Focus Edition.154: 320.

Boomsma, A. 1982. The robustness of LISREL against small sample sizes in factor analysis models. Cited in K.G. J'oreskog\& H. Wold (Eds.).pp. 149-173. Systems Under Indirect Observation: Causality, Structure, Prediction.. Amsterdam: North-Holland.

Boulding, W., A. Kalra, R. Staelin and V. A. Zeithaml. 1993. "A dynamic process model of service quality: from expectations to behavioural intentions". Journal of Marketing Research 30(1): 7-27.

Bowen, D. 2001. "Antecedents of consumer satisfaction and dis-satisfaction (CS/D) on long-haul inclusive tours a reality check on theoretical considerations". Tourism Management 22: 49-61.

Bowen, J. and S. Shoemaker. 1998."Loyalty: a strategic commitment".Cornell and Restaurant and Administration Quarterly 39: 12-25.

Bramwell, B. 1998."User satisfaction and product development in urban tourism”. Tourism Mangement19(1): 3547.

Chon, K-S.1990.“The Role of Destination Image in Tourism: A Review and Discussion”. Revue du Tourisme2: 2-9.

.1992. "The Role of Destination Image in Tourism: An Extension”. Revue du Tourisme 1:2-8.

Cavero, S. and C. Javier. 1997. "Brand Chioce and Marketing Strategy: An Application to the Market of Laundry Detergent for Delicate Clothes in Spain".Journal of International Consumer Marketing 56: 55-68.

Chatzisarantis, N. L. D. \& S. J. H. Biddle. 1998. "Functional significance of psychological variables that are included in the theory of planned behaviour: A self-determination theory approach to the study of attitudes, subjective norms, perceptions of control and intentions". European Journal of Social Psychology 28: 303-322.

Chaudhary, M. 2000. "India's image as a tourist destination - a perspective of foreign tourists". Tourism Management 21: 293-297.

Chaudhuri A. and M.B. Holbrook. 2001."The chain of effects from brand trust and brand affect to brand performance: The role of brand loyalty". Journal of Marketing2001 65(April): 81-93.

Chen, C.F.andD. Tsai. 2007. "How destination image and evaluative factors affect behavioral intentions". Tourism Management28 (4): 1115-1122.

Chen, P. J., andD. L. Kerstetter. 1999. "International students' image of rural Pennsylvania as travel destination". Journal of Travel Research 37: 256-266.

Choi, W. M., A. Chan and J. Wu. 1999. "A qualitative and quantitative assessment of Hong Kong's image as a tourist destination".Tourism Management 20 (1): 361-365.

Chon, K.S. andM.D. Olsen. 1991. "Functional and Symbolic Approaches to Consumer Satisfaction/Dissatisfaction". Journal of the International Academy of Hospitality Research 28: 1-20.

Cole, S. T. andD. Scott.2004."Examining the mediating role of experience quality in a model of tourist experiences". Journal of Travel \& Tourism Marketing 16(1): 70-90.

Conner, M., \& C. J. Armitage. 1998. "Extending the theory of planned behavior: A review and avenues for further research". Journal of Applied Social Psychology 28: 1429-1464.

Conner, M., Norman, P. \& R. Bell. 2002. "The theory of planned behavior and healthy eating". Health Psychology 21(2): 194-201.

Converse, J. M. and Stanley Presser.1986. Survey Questions: Handcrafting the Standardized Questionnaire. Thousand Oaks, CA: Sage Publications.

Cooper, C., J. Fletcher ,D. Gilbert andS. Wanhill. 1993. Tourism.Principles \&Practice. UK: Pitman Publishing.

Council for Economic Plan and Development. 2008. News Letter: Promoting Bikeway Network planned by Government $\quad$ Result is coming out. [Online].Available http://www.cepd.gov.tw/m1.aspx?sNo=0010363\&key=\%e8\%87\%aa\%e8\%a1\%8c\%e8\%bb\%8a. August 2008).

Court, B. andR. A. Lupton. 1997. "Customer Portfolio Development: Modelling Destination Adopters, Inactives and Rejecters". Journal ofTravel Research36(1): 35-43.

Crompton, J. L. 1979. "An Assessment of the Image of Mexico as a Vacation Destination and the Influence of Geographical Location Upon that Image”. Journal of Travel Research14(4): 18-23. 
Crompton, J.L. and L. L. Love. 1995. "The predictive validity of alternative approaches to evaluating quality of a festival". Journal of Travel Research 34(11): 11-24.

Cronin, J. andK. J. Mackey. 1992. "Measuring Service Quality: a Reexamination and Extension". Journal of Marketing 56(1): 125-131.

Cronin, J. J. andS. A. Taylor. 1992. "Measuring service quality: a reexamination and extension". Journal of Marketing56: 55-68.

Crosby, A. L. 1993. The Service QualityHandbook.. New York: AMACOM.

Davidoff, P. G. and D. S. Davidoff. 1983. Sales and Marketing for Travel and Tourism. Rapid City: National Publishers.

Dick, A.S. and K. Basu.1994."Customer Loyalty: Toward an Integrated Conceptual Framework" Journal of the Academy of Marketing Science 22(2): 99-113.

Dobni, Dawn and George M. Zinkhan. 1990. In Search of Brand Image: A Foundation Analysis.Cited inGoldberg, G. Gom and R. W. Pollay (eds.). pp. 110-19. Advances in Consumer Research. M. Provo, UT: Association for Consumer Research.

Doll, J. and I. Ajzen. 1992. "Accessibility and Stability of Predictors in the Theory of Planned Behavior". Journal of Personality \& Social Psychology 63(5): 754-765.

Drake, C., A. A. Gwynne and N. Waite. 1998. "Barclays life coustomer satisfaction and loyalty tracking survey: A demonstration of customer loyalty research in practice". The International Journal of Bank Marketing 16(7):287.

Earl, R. Babbie. 2010. The Basics of Social Research. USA.: Wadsworth.

Echtner, C. M. andJ. R. B. Ritchie. 1993. "The measurement of destinations image: an empirical assessment". Journal of TravelResearch31(4): 3-13.

. 1991. "The Meaning and Measurement of Destination Image". The Journal of Tourism Studies 2(2): 2-12.

Esu, B.B. and V.M.E. Arrey. 2009. "Branding Cultural Festival as a Destination Attraction: A Case Study of Calabar Carnival Festival”. International Business Research 2(3): 182-192.

Fakeye, P. C. andJ. L. Crompton. 1991. "Image Differences Between Prospective, First-Time, and Repeat Visitors to the Lower Rio Grande Valley". Journal of Travel Research 30(2): 10-16.

Fishbein, M. \& I. Ajzen. 1975. Belief, Attitude, Intention and Behaviour: An Introduction to Theory and Research.USA.:Addison-Wesley.

Fombrun, C. J. andM. Shanley. 1990."What is in a name? Reputation building and corporate strategy".Academy of Management Journal 33(2): 233-259.

Font, X. 1997."Managing the tourist destination's image".Journal ofVacation Marketing3(2): 123-131.

Fornell, C. 1992. "A national customer satisfaction barometer: the Swedish experience". Journal of Marketing56: 6-21.

Fornell, C. and D. F. Larcker. 1981. "Evaluating structural equation models with unobservable variables and measurement error". Journal of Marketing Research 48: 39-50.

Fornell, C., M. D. Johnson, E. W. Anderson, J. Cha andB. E. Bryant. 1996. "The American customer satisfaction index: nature, purpose, and findings". Journal of Marketing60: 7-18.

Fredericks, J. O., R. R. Hurd andJ. M. Slater II. 2001.“Connecting customer loyalty to financial results". Marketing Management 28(2): 75-79.

Galea, M. N. \& S. R. Bray. 2006. "Predicting walking intentions and exercise in individuals with intermittent claudication: An application of the theory of planned behavior". Rehabilitation Psychology 51: 620-628.

Gallarza, M.,J.Gil andH. Calderon. 2002. "Destination image. Towards a conceptual framework".Annals of Tourism Research 29(1): $56-78$.

Garvin, D. A. 1987. "Competing on the Eight Dimensions of Quality". Harvard Business Review 65 (6):101-109.

George, B. P. andB. P. George. 2004. "Past visit and the intention to revisit a destination: place attachment as the mediator and novelty seeking as the moderator". The Journal of Tourism Studies 15(2): 51-66.

Greenslade, Jaimi H.\& Katherine, M.White. 2005. "The prediction of above regular participation in volunteerism: A test of the theory of planned behaviour and the volunteers functions inventory".Journal of Social Psychology145(2): 155-172.

Grönroos, C. 1984. "A service quality model and its marketing implications". European Journal of Marketing 18 (4): $36-44$. 
Hair, J. E., R. E. Anderson, R. L. Tatham andW. C. Black. 1998. Multivariate Data Analysis. 5th ed. Upper Saddle River, NJ: Prentice-Hall.

Han, H., Lee, S. \& C. K. Lee. 2011. "Extending the theory of planned behavior: Visa exemptions and the traveller decision-making process". Tourism Geographies 13(1): 45-74.

Hanyu, K. 1993. "The affective meaning of Tokyo: verbal and nonverbalapproaches". Journal of Environmental Psychology 13: 161-172.

Kassem, N. O., Lee, J. W., Modeste, N. N. \& P. K. Johnston. 2003. "Understanding soft drink consumption among female adolescents using the Theory of Planned Behavior". Health Education Research 18: 278291.

Hausenblas, H. A., Carron, A. V. \& D. E. Mack. 1997. "Application of the theories of reasoned action and planned behavior to exercise behavior: A meta-analysis".Journal of Sport \& Exercise Psychology 19(1): $36-51$.

Heskett, J.L., T.O. Jones, G.W. Loveman, W.E. Sasser and L.A. Schlesinger. 1994. "Putting the service-profit chain to work".Harvard Business Review2(March-April): 164-74.

Heung, V. andE. Cheng. 2000. "Assessing tourists' satisfaction with shopping in the Hong Kong special administrative region of China".Journal of Travel Research38(2): 396-404.

Hou, J., C. Lin andD. B. Morais. 2005."Antecedents of Attachment to a Cultural Tourism Destination: The Case of Hakka and Non-Hakka Taiwanese Visitors to Pei-Pu, Taiwan”. Journal of Travel Research 44(2): 221233.

Hrubes, D., Ajzen, I. \& J. Daigle. 2001. "Predicting hunting intentions and behavior:An application of the theory of planned behavior". Leisure Sciences 23(3): 165-178.

Hsu, C., L. Killion, G. Brown, M. Gross andS. Huang. 2008. Tourism Marketing: An Asian-Pacific Perspective. Milton, Australia: John Wiley \& Sons.

Huh, J. 2002. Tourist Satisfaction with Cultural/Heritage Site: The Virginia Triangle, Unpublished M.Sc. [Online] Available http://www.scholar.lib.vt.edu/thesis/available/ etd-0154002-1710/unrestrited/thesis.pdf. (12 November 2011).

Hui, T. K., D. Wan and A. Ho. 2007."Tourists' satisfaction, recommendation and revisiting Singapore”. Tourism Management 28(4): 965-975.

Hunt, J. D. 1975. "Image as a factor in tourism development". Journalof Travel Research13(3): 1-7.

Jang, S. \& Y. Namkung. 2009. "Perceived quality, emotions, and behavioral intentions: Application of an extended Mehrabian-Russell model to restaurants". Journal of Business Research 62: 451-460.

Jones, T. O. andW. E. Sasser. 1995."Why Satisfied Customers Defect”.Harvard Business Review 73(6): 88-99.

Kandampully, J. 1998."Service Quality to Service Loyalty: A Relationship Which Goes Beyond Customer Services”.Total Quality Management 9(6): 431-443.

Kotler, O., D. H. HaiderandY. Rein. 1993. Marketing Places: Attracting Investment, Industry and Tourism to Cities, States and Nations. New York: The Free Press.

Kotler, P., J. Bowen and J. Makens. 1996. Marketing for Hospitality and Tourism. Prentice Hall: New Jersey.

Kozak, Metin. 2001. "Repeaters' Behavior at Two Distinct Destinations". Annals of Tourism Research 28(3): 784-807.

Kozak, M. and M. Rimmington.2000. "Tourist satisfaction with Mallorca, Spain, as an off-season holiday destination".Journal of Travel Research38(1): 260-269.

Lam, T. \& C. H. C. Hsu. 2006. "Predicting behavioral intention of choosing a travel destination". Tourism Management 27(4): 589-599.

Latimer, A. M., Silander, J. A. \& R. M. Cowling. 2005. "Neutral ecological theory reveals isolation and rapid speciation in a biodiversity hot spot". Science 309: 1722-1725.

Latimer, A. E. \&Ginis, K. A. Martin. 2005. "The theory of planned behavior in prediction of leisure time physical activity among individuals with spinal cord injury". Rehabilitation Psychology 50(4): 389-396.

Lau, A. L. S. \& B. McKercher. 2004. "Exploration versus acquisition: A comparison of first-time and repeat visitors". Journal of Travel Research 42(3): 279-285.

Lawson, F. andM. Baud-Bovy. 1997. Tourism and Recreational Development. London: Architectural Press.

Lee, C. C. 2001. "Predicting tourist attachment to destinations". Annals Tour. Res. 28(1): 229-232. 
Lee, C. C., K. Backman and S. Backman. 1997. Understanding Antecedents of Repeat Visitation and Tourists' Loyalty to a Resort Destination.Proceedings of the 1997 Travel and Tourism Research Association Annual Conference.USA.: Boulder CO.

Lee, J., A .R. S. Graefe andR.C. Burns. 2004. "Service quality, satisfaction and behavioral intention among forest visitors". Journal of Travel \& Tourism Marketing 7(1): 73-82.

Lee,G., L.A. Cai and O'Leary, J.T. 2006. "WWW.Branding.States.US:An analysis of brand-building elements in the US state tourism websites". Tourism Management. 27 (5): 815-826.

Leiper, N. 1990."Tourist attraction systems". Annals of Tourism Research 77(3): 367-384.

Liljander, V. andT. Strandvick. 1997. "Emotions in service satisfaction". International Journal Services Industry Management 8(2): 148-169.

Loureiro, S. M. C. andF. J. M. Gonzalez. 2008. "The importance of quality, satisfaction, trust, and image in relation to rural tourist loyalty". Journal of Travel \&Tourism Marketing 25(2):117-136.

Mann, P. S. 1995. Introductory Statistics. 2nd ed. USA.: Wiley.

Mansfeld, Y. 1992. "From motivation to actual travel". Annals ofTourism Research19: 399-419.

Marsh, H. W., Balla, J. R. \& R. P. McDonald. 1988. "Goodness-of-fit indexes in confirmatory factor analysis: The effect of sample size".Psychological Bulletin 103, 3: 391-410.

Martin, H.S. andI. R. Bosque. 2008. "Exploring the cognitive-affective nature of destination image and the role of psychologicial factors in its formation". Tourism Management 29(2): 263-277.

Mat Som, A. P., S. F. MostafaviShiazi, A. MarzukiandJ. Jusoh. 2011. "A critical analysis of tourist satisfaction and destination loyalty". Journal of Global Management 2(1): 178-183.

Methlie, L.B., and H. Nysveen. 1999. "Loyalty of On-line Bank Customer".Journal of Information Technology 14: 375-386.

Middleton, V. T. C. 1994. Tourist product.Cited in Witt, S. \&Moutinho, L. (Eds.).Tourism Marketing and Management Handbook. pp. 573-576. Hempel Hempstead: Prentice-Hall.

Millán, Á. andÁ. Esteban. 2004. "Development of a multiple-item scale for measuring customer satisfaction in travel agencies services".Tourism Management 25(2): 533-546.

Milman, A. andA. Pizam. 1995. "The role of awareness and familiarity with a destination: the central florida case". Journal of TravelResearch33(3): 21-27.

Moutinho, L. 1987. “Consumer behaviour in tourism. European”.Journal of Marketing21(10): 5-44.

Narins, P. 1999. Guidelines for Creating Better Questionnaires.[Online].Available http://www.spss.com/newsltrs/kw/Kw58/Survey.html (6January 2000).

Ott, R. Lyman. 1993. An Introduction to Statistical Methods and Data Analysis. California USA: Duxbury Press.

O'Leary, S. andJ. Deegan. 2003. "People, pace, place: Qualitative and quantitative images of Ireland seize Tourism destination in France". Journal of Vacation Marketing 9(3): 213-226.

. 2005. "Ireland's image as a tourism destination in France: Attribute importance and performance". Journal of Travel Research 43(3): 247-260.

Oliver, R. L. 1980a. "A cognitive model for the antecedent and consequences of satisfaction decisions". Journal of Marketing Research 27: 460 -469.

. 1980b. "A cognitive model of the antecedents and consequences of satisfaction decisions".Journal of Marketing Research17: 460-469.

. 1997. Emotional Expression in the Satisfaction Response. Cited inSatisfaction: A Behavioral Perspective on the Consumer. pp. 291-325. Boston: Irwin.

Oliver, R. L. and J. E. Swan. 1989. "Consumer perceptions of interpersonal equity and satisfaction in transactions: a field survey approach". Journal of Marketing53: 21-35.

Parasuraman, A., V.A. ZeithamlandL. Berry. 1985. "A conceptual model of service quality and its implication for future research". Journal of Marketing 49(3): 41-50.

. 1988. "SERQUAL: a multiple item scale for measuring consumer perception of service quality". Journal of Retailing 6(1): 12-40.

Pavlou, P. A. \& M. Fygenson. 2006. "Understanding and predicting electronic commerce adoption: An extension of the theory of planned behavior". Management Information Systems Quarterly 30(1): 115-143.

Pearl, Judea. 2000. Causality: Models, Reasoning, and Inference.UK: Cambridge University Press. 
Phelps, A. 1986."Holiday destination image the problem of assessment: an example developed in Menorca". Tourism Management7(3): 168-180.

Philip, G. andS. A. Hazlett. 1996. "The measurement of service quality: a new P-C.P. attributes model". International Journal of Quality and Reliability Management 14(3): 260-288.

Pierro, A., Mannetti, L. \& S. Livi. 2003. "Self-identity and the theory of planned behavior in the prediction of health behavior and leisure activity". Self \& Identity 2: 47-60.

Pike, S. 2002. "Destination image analysis: A review of 142 papers from 1973 to 2000". Tourism Management23: 541-549.

Pizam, A., Y. Neumann andA. Reichel. 1978. "Dimensions of tourist satisfaction with a destination". Annals of Tourism Research 5: 314-322.

Pizman, A. andA. Millman. 1993. "Dimensions of tourist satisfaction with a destination". Annals of Tourism Research 5: 314- 322.

Pritchard, Mark P. and R. Dennis, Howard. 1997. "The Loyal Traveller: Examining a Typology of Service Patronage".Journal of Travel Research2(Spring): 2-10.

Reichheld, F.F. andW.E. Sasser, Jr. 1990."Zero defections. Quality comes to services”. Harvard Business Review 68(5): 105-111.

Reichheld, F.F. and P. Schefter. 2000."E-loyalty: your secret weapon on the Web".Harvard Business Review3(July-August): 105-13.

Rengert, G. F., A. R. Piquero andP. R. Jones. 1999. "Distance decay re-examined”. Criminology 37(2): 427-445.

Rhodes, R. E., Macdonald, H. M. \& H. A. McKay. 2006. "Predicting physical activity intention and behaviour among children in a longitudinal sample". Social Science \& Medicine 62(12): 3146-3156.

Rittichainuwat, B. N., H. Qu and T. Brown. 2001. Thailand's International Travel Image: Mostly Favorable. Bangkok: Cornell Hotel and Restaurant Administration Quarterly.

Roberts, C. M., G. Branch, R. H. Bustamante, J. C. Castilla, J. Dugan, B. S. Halpern, K. D. Lafferty, H. Leslie, J. Lubchenco, D. McArdle, M. Ruckelshaus andR. R. Warner. 2003.“Application of ecological criteria in selecting marine reserves and developing reserve networks". Ecological Applications 13: S215-S228.

Rust, R.T., A.J. Zahorik and T.L. Keininghan. 1993. Return on Quality. Chicago, IL: Probus Publishing.

S.oderlund, M. 1998."Customer satisfaction and its consequences of customer behavior revisited: The Impact of different levels of satisfaction on word of mouth, feedback to the supplier and loyalty". International Journal of Service Industry Management 9(2): 169-188.

Seaton, A. V. andM. M. Benett. 1996. Marketing Tourism Products.Concepts, Issues, Cases. London: International Thomson Business Press.

Shamsuddin, S. andN. Ujang. 2008. "Making places: The role of attachment in creating the sense of place for traditional streets in Malaysia". Habitat International. 32(3): 399-409.

Shoemaker, S. andR. C. Lewis. 1999. "Customer loyalty: the future of hospitality marketing". International Journal of Hospitality Management 18(4): 345-370.

Simon, Herbert. 1953. Causal ordering and identifiability. Cited in Hood, W.C.and Koopmans, T.C..pp. 49-74. Studies in Econometric Method. New York: Wiley.

Sirgy, J. M. 1984. “A Social Cognition Model of Consumer Satisfaction/Dissatisfaction”. Psychology and Marketing 1(2): 27-44.

Sirgy, M. Joseph and A. Coskun,Samli. 1985. "A path analytic model of store loyalty involving self-concept, store image, socioeconomic status, and geographic loyalty".The Journal of the Academy of Marketing Science 13(Summer): 265-91.

Smith, M. P. 2001. Transnational Urbanism: Locating Globalization. Malden, MA: Blackwell.

Smith, V. 1998."War and Tourism: An American Ethnography”.Annals of Tourism Research 25(1): 202-27.

Sports Affairs Council of Executive Yuan. 2002. Plan to Double Exercise Population. [Online].Available http://www.cc.nctu.edu.tw/ mclub/meichu/upload/upload_129.doc. （12 Jan 2011).

Stabler, M. J. 1988. The Image of Destination Regions: Theoretical and Empirical Aspects. Cited in Goodall, B. and Ashworth, G. (Eds.). Marketing in the Tourism Industry: The Promotion of Destination Regions. pp. 133-159. London: Rougledge.

Statistics Solutions. 2009. [Online]. Available http://www.statisticssolutions.com/ (29 June 2011).

Taiwan Tourism Bureau "TAIWAN TOURISM AND HOSPITALITY IN FUTURE PLAN". 2010. [Online]. Available http://www.ey.gov.tw/ct.asp?xItem= 97 (2 September 2011). 
Telisman-Kosuta, N. 1989.Tourism Destination Image.Cited inWitt, S. F. and Moutinho, L. (Ed.).Tourism Marketing and Management Handbook. pp. 557-561. Cambridge: Prentice Hall.

Tepeci, M., 1999."Increasing brand loyalty in the hospitality industry".International Journal of Contemporary Hospitality Management 11(5): 223-230.

Thomas, R. J. 1995. New Product Success Stories: Lessons from Leading Innovators. USA: John Wiley \& Sons.

Toh, S. L., J. C. H. Goh, P. H. Tan and T. E.Tay. 1993. "Fatigue Testing of Energy Storing Prosthetic Feet".Prosthetics and Orthotics International 17:180-188.

Valle, O. D., S. A. Silva, J. Mendu andM. Guerreco. 2006. "Tourist satisfaction and destination loyalty intention: structural and categorical analysis". International Journal of Business Science and Applied Management 1(1): 25-44.

Vaughan, D. R. andJ. R. Edwards. 1999."Experiential perceptions of two winter sun destinations: The Algarve and Cyprus".Journal of Vacation Marketing 5: 356-368.

Weaver, D. andL. Lawton. 2002. Tourism Management. Milton, Australia: Jhon Wiley \& Sons Australia, Ltd.

Weller, S. C. andA. K. Romney. 1988. Systematic Data Collection. CA: Sage, Newbury Park.

White, C. J. 2002. "Emotions, Gender and Destination Visitation Intentions".I ColoquioPredoctoralEuropeo of Tourism and Leisure. ESADE-IMHI (Cornell-ESSEC).[Online].Available http://www.esade.es/cedit2003/cast/est papsen.htm. (10 June 2011).

Wong, Amy and Sohal, Amrik. 2003. "Service quality and customer loyalty perspectives on two levels of retail relationships".Journal of Services Marketing 17 (5): 495-513.

Wright, Sewall S. 1921. "Correlation and causation”. Journal of Agricultural Research 20: 557-85.

Yoon, Y. andM. Uysal. 2005. "An examination of the effects of motivation and satisfaction on destination loyalty: A structural model". Tourism Management 26(1): 45-56.

Yu, Y. T. andA. Dean. 2001. "The contribution of the emotional satisfaction to consumer loyalty".International Journal Services Industry Management 12(3): 234-250.

Zeithaml, V. A. andM. J. Bitner. 2000. Services Marketing: Integrating Customer Focus Across the Firm. Madison: McGraw-Hill. 